\title{
THE ANTEQUERA MEGALITHIC SITE IN THE WORK OF GEORG AND VERA LEISNER: A REVIEW
}

\section{EL SITIO DE LOS DÓLMENES DE ANTEQUERA EN LA OBRA DE GEORG Y VERA LEISNER: UNA REVISIÓN}

\author{
LEONARDO GARCÍA SANJUÁN \\ Departamento de Prehistoria y Arqueología. Facultad de Geografía e Historia. Universidad de Sevilla. \\ C/Doña María de Padilla s/n, 41004, Sevilla. Correo-e: Igarcia@us.es. (D https://orcid.org/0000-0002-8404-9252 \\ CORONADA MORA MOLINA \\ Grupo de Investigación ATLAS (HUM-694). Departamento de Prehistoria y Arqueología. Universidad de Sevilla. \\ C/Doña María de Padilla s/n, 41004, Sevilla. Correo-e: coronada_mora@us.es. D https://orcid.org/0000-0002-5062-2604 \\ MARTIN BARTELHEIM \\ Institut für Ur- und Frühgeschichte und Archäologie des Mittelalters. Abteilung für Jüngere Urgeschichte und Frühgeschichte. \\ Philosophische Fakultät. Universität Tübingen. Schloß Hohentübingen, 72070, Tübingen. Correo-e: martin.bartelheim@uni-tuebingen.de. \\ (D) https://orcid.org/0000-0002-7745-9712
}

\begin{abstract}
The Antequera dolmens site (Malaga, Spain), included in the UNESCO World Heritage List since July 2016, has a research history of almost 200 years that goes back to the work of Rafael Mitjana y Ardison in the 1840s. After the discovery of the Viera dolmen and El Romeral tholos, in 1903 and 1904 respectively, the research of the great megalithic site received a renewed impulse. Published in 1943, the first volume of the corpus of Iberian megalithic monuments by Georg and Vera Leisner (Die Megalithgräber der Iberischen Halbinsel, Erster Teil: Der Süden) was to become the most detailed study of the Antequera site during the second half of the 20th century, despite the fact that being published in German limited its penetration among the Spanish scholarship. Here, we review the importance of the work of the Leisners to understand the Antequera megaliths in light of the results of the research that has been undertaken in the last 15 years. Many of the issues raised by the German couple continue to be fully pertinent within the context of today's research on these monuments. In addition, to facilitate future access to their work, this paper is accompanied by full translations into English and Spanish of the Leisners's text on the Antequera megaliths.
\end{abstract}

Keywords: Recent Prehistory, Neolithic, Copper Age, Iberian Peninsula, Megaliths, Antequera, Architecture.
Resumen: El sitio de los dólmenes de Antequera (Málaga, España), inscrito en la Lista del Patrimonio Mundial de UNESCO desde julio de 2016, cuenta con una historia de investigación de casi 200 años que se remonta al trabajo de Rafael Mitjana y Ardison en la década de 1840. Tras el descubrimiento del dolmen de Viera y el tholos de El Romeral, en 1903 y 1904 respectivamente, la investigación del gran sitio megalítico antequerano experimentó un fuerte impulso. Publicado en 1943, el primer volumen del gran corpus de monumentos megalíticos ibéricos de Georg y Vera Leisner (Die Megalithgräber der Iberischen Halbinsel. Erster Teil: Der Süden) habría de convertirse en el estudio más detallado del sitio antequerano durante toda la segunda mitad del siglo XX, a pesar de que el hecho de estar publicado en alemán lo hacía de difícil acceso para muchos estudiosos españoles. En este artículo revisamos la importancia de la obra de los Leisners para entender los megalitos antequeranos a la luz de los resultados de las investigaciones que se vienen desarrollando desde hace 15 años. Son muchas las cuestiones planteadas en la obra del matrimonio alemán que siguen teniendo plena vigencia en la investigación actual de estos monumentos. Además, para facilitar el futuro acceso a su obra, el texto se acompaña de sendas traducciones al inglés y al español.

Palabras clave: Prehistoria Reciente, Neolítico, Edad del Cobre, península ibérica, Megalitos, Antequera, Arquitectura. 


\section{INTRODUCTION}

The Antequera megalithic site (Malaga, Spain), listed as a UNESCO World Heritage Site since July 2016, has a long history of archaeological research that goes back almost two hundred years. Although this probably makes it one of the Iberian prehistoric sites with the longest research history (if not the longest) its unfolding as a subject of study has been anything but straightforward. It started when Rafael Mitjana y Ardison carried out several excavation seasons at Menga at unspecified dates between 1842 and 1847. The resulting publication, a booklet titled Memoria sobre el Templo Druida Hallado en las Cercanías de la Ciudad de Antequera (Memoir of the Druidic Temple Found in the Vicinity of the City of Antequera) (Mitjana y Ardison 1847), triggered a period of intense interest on this magnificent prehistoric monument, and was followed by numerous studies and publications (see Tenison 1853; Rojas y Rojas 1861; Germond de Lavigne 1866; Wattenbach 1869; Talbot 1869; Hancock 1882; Harlé 1887). As a consequence, Menga would achieve great fame, thus becoming the first-ever Spanish prehistoric site to attain, in 1886, a declaration as National Monument. At the same time, it became a reference for the study of the megalithic phenomenon world-wide (for a detailed discussion see Sánchez-Cuenca López 2011).

After the discovery of the Viera dolmen and El Romeral tholos, in 1903 and 1904 respectively, the Antequera megalithic site received further attention, as reflected in various major publications that provided accounts of the morphology, dimensions, state of preservation and finds of the newly found monuments (Gómez-Moreno Martínez 1905; Velázquez Bosco 1905; Mélida 1906; Amador de los Ríos 1907). In the first three decades of the $20^{\text {th }}$ century several publications contributed to a renewed international projection to these monuments, setting the basis for the debate concerning the chronology, cultural background and, to a lesser extent, social context, of the megalithic phenomenon in southern Iberia (see for example Obermaier 1919, 1920; Leeds 1921; De Mortillet 1921; Paris 1921; De Mergelina 1922; Burkitt 1926; Hemp 1934). Perhaps the most systematic of these descriptions was that authored by Georg and Vera Leisner in their great corpus of Iberian megaliths (Leisner and Leisner 1943: 173-185).

The study of the Leisners is one of the most important ever published about the Antequera megaliths. To a large extent, this is due to the fact that it presents a competent discussion of the substantial amount of literature that, already by the 1930 s, had been published about the monuments, as well as fresh field observations. But also it is due to the organised and systematic way in which the information is presented. In fact, once published, their report became a reference for decades. Between the 1940s and the late 1980s the investigation of the Antequera megaliths hardly advanced at all, their interpretation stagnating from both a theoretical and methodological standpoint. As a result, the presence of this great site in the international debate faded to the point of almost disappearing - see for example Daniel 1973 for a rare exception. This situation, undoubtedly connected to the poverty of intellectual resources available to Spanish archaeology during the years of the Franco dictatorship (1936-1975), only started to subside between 1985 and 2005, when the Andalusian regional government promoted new research at the site and surrounding region. In those two decades, researchoriented excavations were carried out by the universities of Malaga and Granada. In addition, several rescue excavations were undertaken in response to major public works (motorways, high-speed railway) and the accelerated urban growth of Antequera. However, beyond some interim project reports and subject-specific articles (Ferrer Palma 1997a, 1997b; Ferrer Palma et al. 2004; Marqués Merelo et al. 2004a, 2004b), those research-oriented excavations were never followed by systematic post-excavation work or thorough publication. It was not until well into the $21^{\text {st }}$ century, almost seventy years after the publication of the Leisners's work, that new monographs with full and detailed descriptions of the monuments (Márquez Romero and Fernández Ruiz 2009) and original scientific contributions (Ruiz González 2009; García Sanjuán and Mora Molina 2018) were published.

Considering the above, and in light of the research we have undertaken in Antequera in the last decade (see García Sanjuán 2009 for a preliminary formulation of aims and García Sanjuán et al. 2018 for a recent discussion of results), a review of the significance of the work by the Leisners can help to put the present-day research in perspective. There are a number of reasons for this. First, it is worth comparing the description provided by them, one of the most detailed ever published, with the discoveries made in the last ten years. Second, it is important to correctly position their contribution within the research history of the site, something that has been often amiss partly because of the fact that the original text was in German, which made its access difficult for Spanish scholars. In order to prevent this from happening again in the future, this paper includes a double 
translation of the original text by the Leisners into Spanish and English - see supplementary information. ${ }^{1}$

\section{THE WORK OF THE LEISNERS}

Georg and Vera Leisner, dedicated their lives to the study of the Iberian megalithic phenomenon, a field they pioneered. Their efforts led to the publication of the earliest compilation of megalithic monuments in southern, eastern and western Iberia (Leisner and Leisner 1943, 1956 and 1959; Leisner and Veiga Ferreira 1963; Leisner 1965; Leisner and Ribero 1968; etc.). Their work has been a major reference ever since, which is all the more remarkable considering it was largely conducted during a convulse time of European history, including the period between the two world wars (1918-1939), the Second World War itself (1939-1945) and, in Iberia, the Portuguese Military Dictatorship (1926-1933) and Salazar's Estado Novo (1933-1974) as well as the Spanish Civil War (1936-1939) and Franco Dictatorship (1939-1975).

Georg Leisner (1870-1957) was born in Kiel (Germany) (Almagro Basch 1957-1958: 294; Boaventura and Langley 2007: 169), while Vera de la Camp (18851972), known as Vera Leisner throughout her professional career, was born in New York (United States of America), although she spent a great deal of her early years in Hamburg and Eisenach (Boaventura and Langley 2011: 303; Sousa et al. 2015: 269-270). After their marriage in 1909, the Leisners lived in Munich until the end of the First World War (Boaventura and Langley 2011: $303)$, in which Georg served as an officer of the German army (Almagro Basch 1957-1958: 294; Boaventura 2017: 132) and Vera served as a nurse (Boaventura 2017: 132). Subsequently, the couple bought a farm in Höhenberg (Bavaria), where they worked and lived until a trip to Italy in 1924-1925, triggered their interest in archaeology (Boaventura 2017: 132).

In 1926, Georg, and also very probably Vera, participated in an expedition to Egypt devoted to the study of Nubian rock art under the direction of Leo Frobenius, from the University of Frankfurt's Institut für Kulturmorphologie (Boaventura 2017: 132). Upon their return to Germany in 1927, and encouraged by Hugo Obermaier, then a Professor at the Complutense University of Madrid, Georg started a doctorate at the

1. The text translated into English and Spanish in Supplementary information in digital version http://dx.doi.org/10.12795/ spal.2019.i28.15
University of Marburg under the supervision of Gero von Merhart. His doctoral thesis, on the subject of megalithic monuments in Galicia and northern Portugal, was successfully submitted in 1932 (Sousa et al. 2015: 270; Boaventura 2017: 132). Although she also started a doctorate at the University of Marburg, Vera never finished her $\mathrm{PhD}$ thesis. In 1960 the University of Freiburg awarded her a doctorate honoris causa (Sousa et al. 2015: 270).

The couple's first long stay in Iberia took place between 1929 and 1930 when, for seven months, they visited several megalithic monuments writing thorough descriptions, taking photographs and drafting plans (Sousa et al. 2015: 270; Boaventura 2017: 132). In a second visit, between 1932 and 1934 they visited numerous other sites and monuments, focusing on the description of architecture and material culture (Boaventura 2017: 133). After compiling and organising all the information they had collected during the months of fieldwork, in 1943 they published the first volume of their megalithic corpus, which included monuments from the Spanish provinces of Guadalajara, Teruel, Valencia, Murcia, Almeria, Granada, Malaga, Cordoba, Seville, Cadiz and Huelva as well as the Portuguese region of Algarve (Leisner and Leisner 1943). After the publication of the first volume of their Megalithgräber, they planned new fieldwork across the Iberian Atlantic façade, starting in November 1943 . However, shortly before their departure, their Munich house was destroyed in an air raid and they lost everything they had. As a result, and in light of the instability in Germany, they decided to settle in Lisbon (Boaventura 2017: 134).

In the years to follow they continued their research work tirelessly, publishing a synthesis of the megalithic phenomenon in the Reguengos de Monsaraz region, in Portugal (Leisner and Leisner 1951), collaborating intensely with Carlos Cerdán Márquez in the study of the megaliths of the Huelva province, in Spain (Cerdán Márquez et al. 1952) and publishing the second volume of Die Megalithgräber der Iberischen Halbinsel (Leisner and Leisner 1956), which completed the previous one with a full descriptive catalogue of monuments. After Georg's death in 1957, Vera continued working indefatigably, making important contributions such as, for example, the first radiocarbon dates of Portuguese megaliths (Leisner and Veiga Ferreira 1963; Leisner 1967), the earliest study of the walled enclosure at Zambujal (Do Paço et al. 1964), which would later become one of the most important sites for the study of the Iberian Copper Age, or of the Carapito 
dolmen (Leisner and Ribeiro 1968). In 1969, aged 84, Vera Leisner still mustered the energy to publish a volume on the Portuguese prehistoric monuments of Praia das Maças and Casainhos (Leisner et al. 1969).

The work of the Leisners is largely acknowledged as one of the most important contributions for the study of the megalithic phenomenon in Iberia and has been discussed several times before (see for example Almagro Basch 1958; Llobregat 1966; Sangmeister 1973; Langley and Boaventura 2007; Blech 2009; Sousa et al. 2015; Boaventura 2017). In the next section we intend to show how important their contribution also was for the study of the great megalithic site of Antequera.

\section{THE ANTEQUERA MEGALITHS}

\subsection{General aspects}

The description of the Antequera megaliths by the Leisners was partly based on the visit they made to the site on February of 1933 (Leisner and Leisner 1943: 182, 184) or 1934 (Leisner 1941: 115), that is to say, barely 30 years after the discovery of Viera and El Romeral and before the first major restoration of the monuments was undertaken in 1940 (for a description see Giménez Reyna 1946: 31-43). That means that they saw the monuments in far more pristine conditions than later scholars and today's visitor.

The data compiled by the German couple were published in two publications: in the first only a brief reference was made to their discovery of a portal stone in the passage of Viera (Leisner 1941: 115) - see discussion below; in the second (Leisner and Leisner 1943: 173-185), they provided a full description of the three monuments, using both their observations as well as the evidence published in the literature available at the time. This publication is an excellent reflection of what was then known about the Antequera megaliths, based on a detailed review of the work by Cayetano de Mergelina (1922) and Manuel Gómez-Moreno Martínez (1905). To the latter, one the scholars who best knew the Antequera monuments, (Bellón Ruiz 2010), the Leisners refer to simply as "Gómez-Moreno". In the translations of the 1943 text we provide as part of this paper we have taken the liberty of referring to him as Manuel Gómez-Moreno Martínez, in order to avoid any confusions with his father, Manuel Gómez-Moreno González, also an archaeologist who studied Menga (see Moya Morales 2004).

In their discussion, the Leisners compared the Antequera megaliths with other major Iberian sites already known at the time, very especially Los Millares (Almeria), Gorafe and Montefrío (Granada), El Gandul and Valencina de la Concepción (Seville), Soto (Huelva) and Alcalar (Algarve). Regarding this point, our translations respect the names used in the original text, including those cases were elements of the names were omitted. For example, that is the case of the La Pastora tholos, part of the Valencina de la ConcepciónCastilleja de Guzmán Copper Age mega-site, which is referred to as "Pastora", or the El Vaquero tholos, included in the El Gandul megalithic necropolis, which is referred to as "Vaquero". It is also the case to the monuments of "Alcalá", which in fact refers to the Portuguese site of Alcalar (Portimão, Algarve).

The study of the Antequera megaliths by the Leisners is remarkable, first because of the detailed architectural analysis of each monument and its components illustrated with updated plans. In the case of Menga and Viera this included new plans [figs. 3, 6 and 8] (Leisner and Leisner 1943: plates 55-57), based on those already published by De Mergelina (1922: plates IV and VIII), while in the case of El Romeral the plans of the Leisners were based on those by De Mergelina (1922: plate I) and Velázquez Bosco (1905: plate XIX y XXVI). Their study also included documentation of newly discovered engravings, described together with those already known (Leisner and Leisner 1943: plate 58). The quality of the graphic descriptions supplied by the Leisners is very good. In fact, it would not be surpassed until, early in the $21^{\text {st }}$ century, high resolution computerised photogrammetry was carried out of all three monuments - these surveys have been published in the case of Menga (Baceiredo Rodríguez et al. 2014) and Viera (Benavides López et al. 2015), although the El Romeral one remains unpublished.

A second relevant contribution of the Leisners's work was the systematic review and precise description of the finds made up until the 1930s. It included drawings of the majority of the described elements (Leisner and Leisner 1943: plate 58) [fig. 4]. It is worth noting that after the large-scale excavations carried out at Menga and Viera by the universities of Malaga and Granada and as a result of restoration work, systematic inventories of finds have only been published for two seasons: the 1988 season in the vinicity of both dolmens (Aranda Jiménez et al. 2015) and the 2005 season in Menga (García Sanjuán and Mora Molina 2018).

A third direct contribution of their description stems from the various photographs of the interior and exterior of the monuments (Leisner and Leisner 1943: plate 97-101, 104-106, 140) [figs. 1, 2, 5 and 


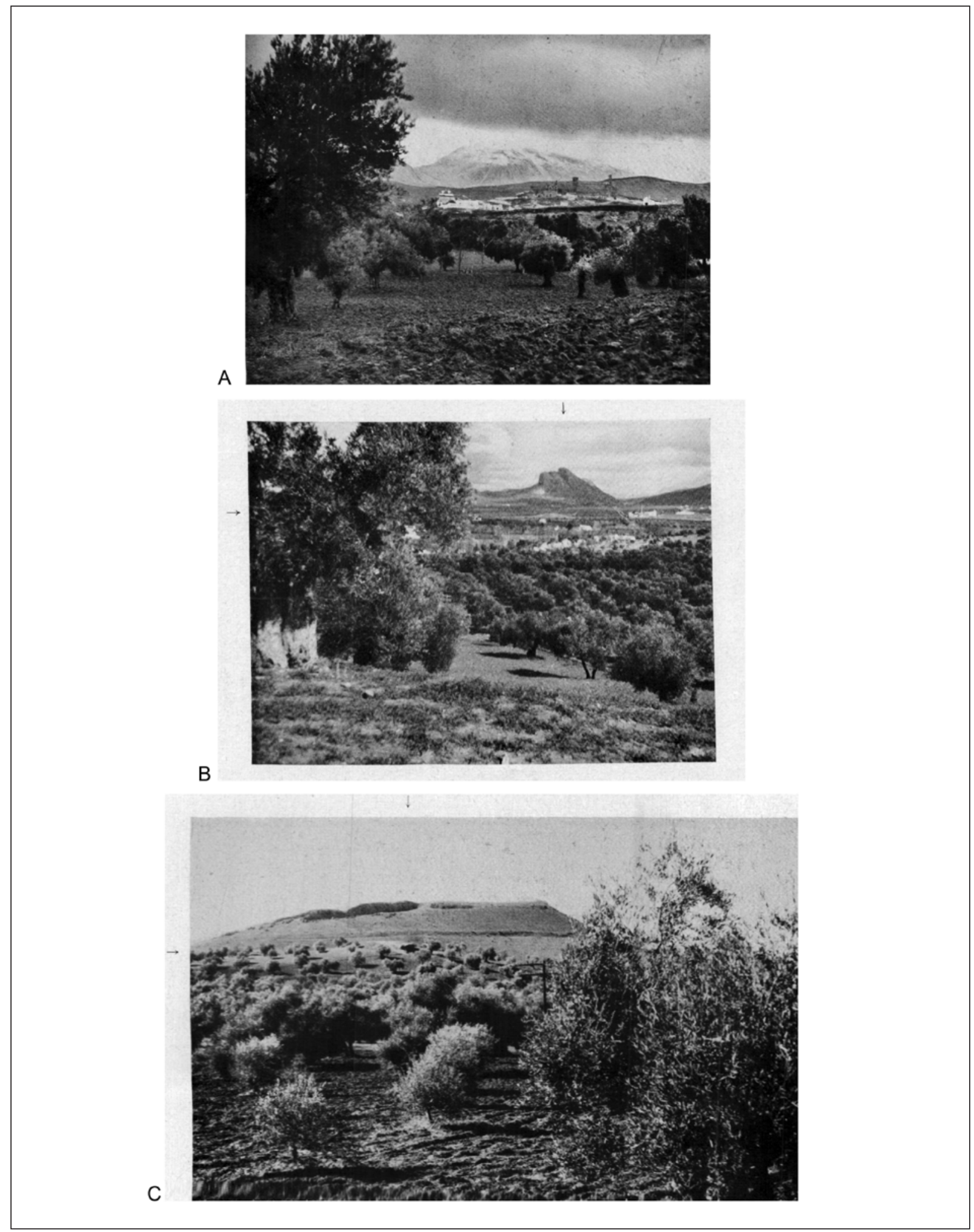

Figure 1. A: View of Antequera from Viera (Leisner and Leisner, 1943: Plate: 97.2). B: View of the mound of El Romeral from Menga, in the intersection between the arrows (Leisner and Leisner, 1943: Plate: 98.3). C: Menga, burial mound, entrance to the tomb in the intersection between ther arrows (Leisner and Leisner, 1943: Plate: 97.1). 


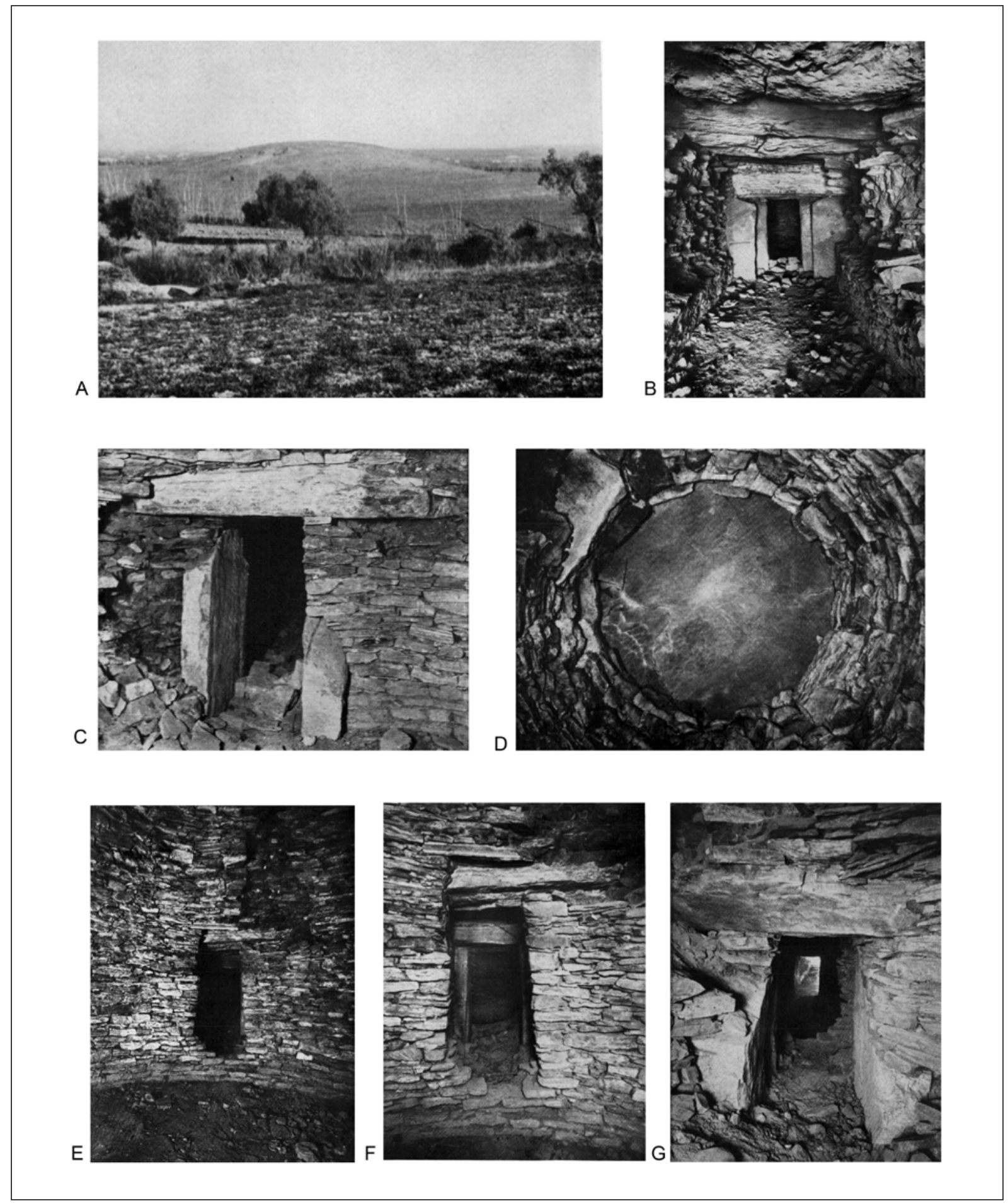

Figure 2. A: El Romeral, mound (Leisner and Leisner, 1943: Plate: 98.1). B: Entrance to the main chamber seen from the passage (Leisner and Leisner, 1943: Plate: 99.1). C: El Romeral. Interior of the main chamber with gate into the passage. (Leisner and Leisner, 1943: Plate: 101.1). D: El Romeral. Culmination of the dome (Leisner and Leisner, 1943: Plate: 102.4). E: El Romeral. Main chamber (Leisner and Leisner, 1943: Plate: 100.2) F: Passage into the secondary chamber as seen from the main chamber (Leisner and Leisner, 1943: Plate: 99.2). G. Secondary chamber with main chamber at the background (Leisner and Leisner, 1943: Plate: 100.1). 


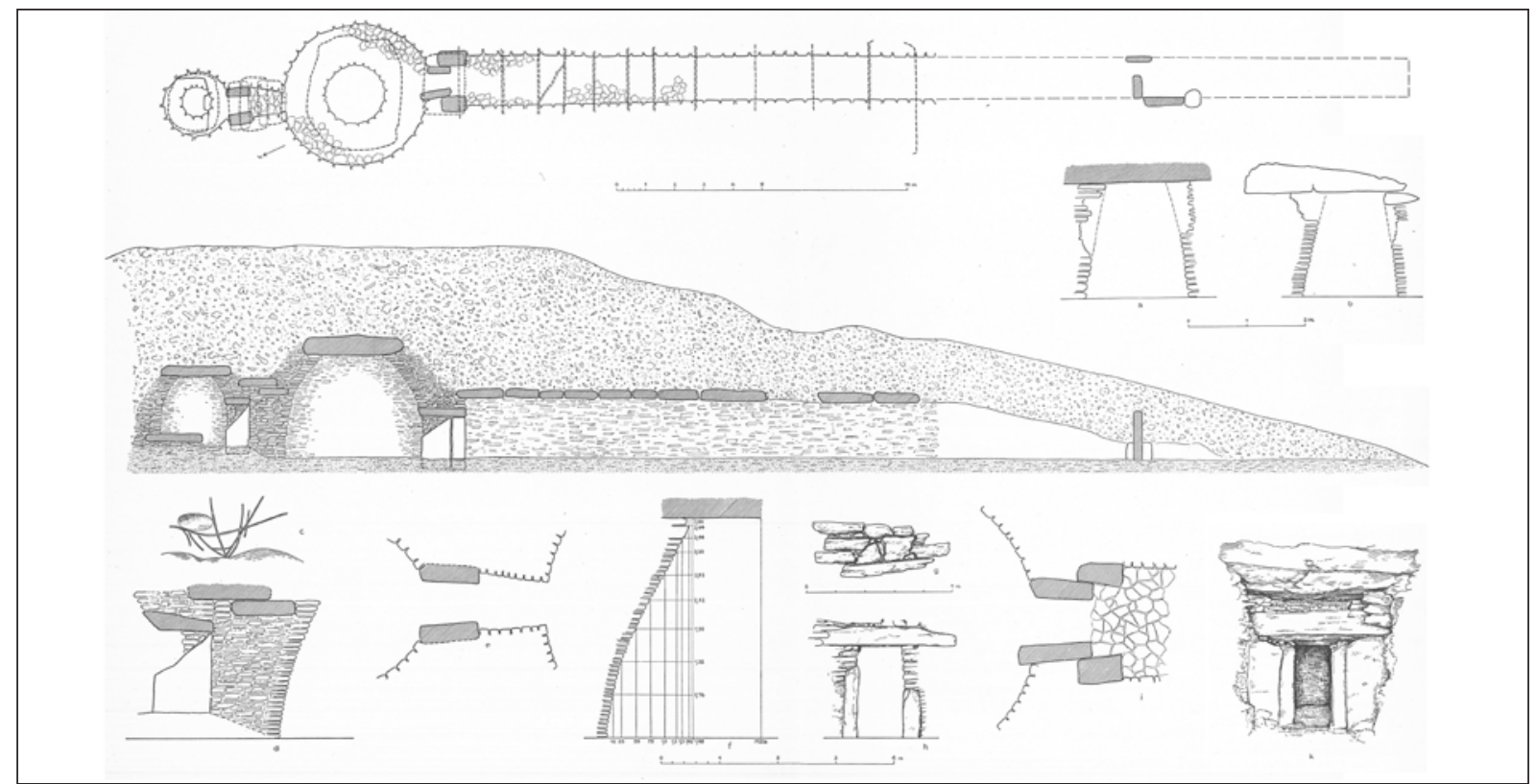

Figure 3. Plan, section and engraving of El Romeral (Leisner and Leisner, 1943: Plate: 55).

7], which are a valuable resource to understand their state of preservation at the time. In particular, these photos are nowadays a very useful tool to assess the surroundings of the three monuments, which in the 1930s was far less altered than it is today. The accelerated urban growth since the 1960s, and especially from the 1980s onwards, has transformed the Antequera lowlands where the megaliths are located quite substantially, which now includes two major motorways, a high-speed railway and an industrial state. This is clearly noticeable in the absence of those elements in all three photos included in fig. 1. Fig. 1A shows a clear view of the city from the dolmen (Leisner and Leisner 1943: plate 97.2). Today this view is blocked by a petrol station and several buildings erected since the 1960s around the old city of Antequera. Fig. 1B shows how 'clear' the line of sight was between Menga and La Peña de los Enamorados (and El Romeral, its position marked by arrows outside the photo frame) (Leisner and Leisner 1943: plate 98.3) before the construction of the industrial state that today spans for several miles east of Antequera. Fig. 1C shows Menga from the south-east, the arrows outside the photo frame showing the position of the dolmen's entrance (Leisner and Leisner 1943: plate 97.1); in this case the topography of the area east to the dolmen can be seen in its original state, prior to the regrettable massive intervention undertaken in the late 1980s to build a gigantic 'interpretation centre', which involved a major removal of soil that was not archaeologically documented.

\subsection{Specific aspects}

\subsubsection{El Romeral}

Apart from the general contribution outlined above, there are several specific points in which the description and analysis of the Leisners remain, even today, of great scientific interest. That is particularly the case with El Romeral, the least studied of the three monuments. To take one example, the Leisners mention that,

...recently, trenches have been opened that prove the artificial character of the mound, since features of black soil and organic remains mixed with sand, mud and pebbles were found. According to P. Paris, in the northern area of the mound there is a second construction, 'some kind of gallery that descends steeply and does not lead to a chamber. From it, a small corridor turns to the left and to the right, near the entrance, another corridor behind which a larger room can be seen'. To this date, it has not been possible to specify whether these are galleries made by looters or they were really part of the original construction (Leisner and Leisner 1943: 174). 


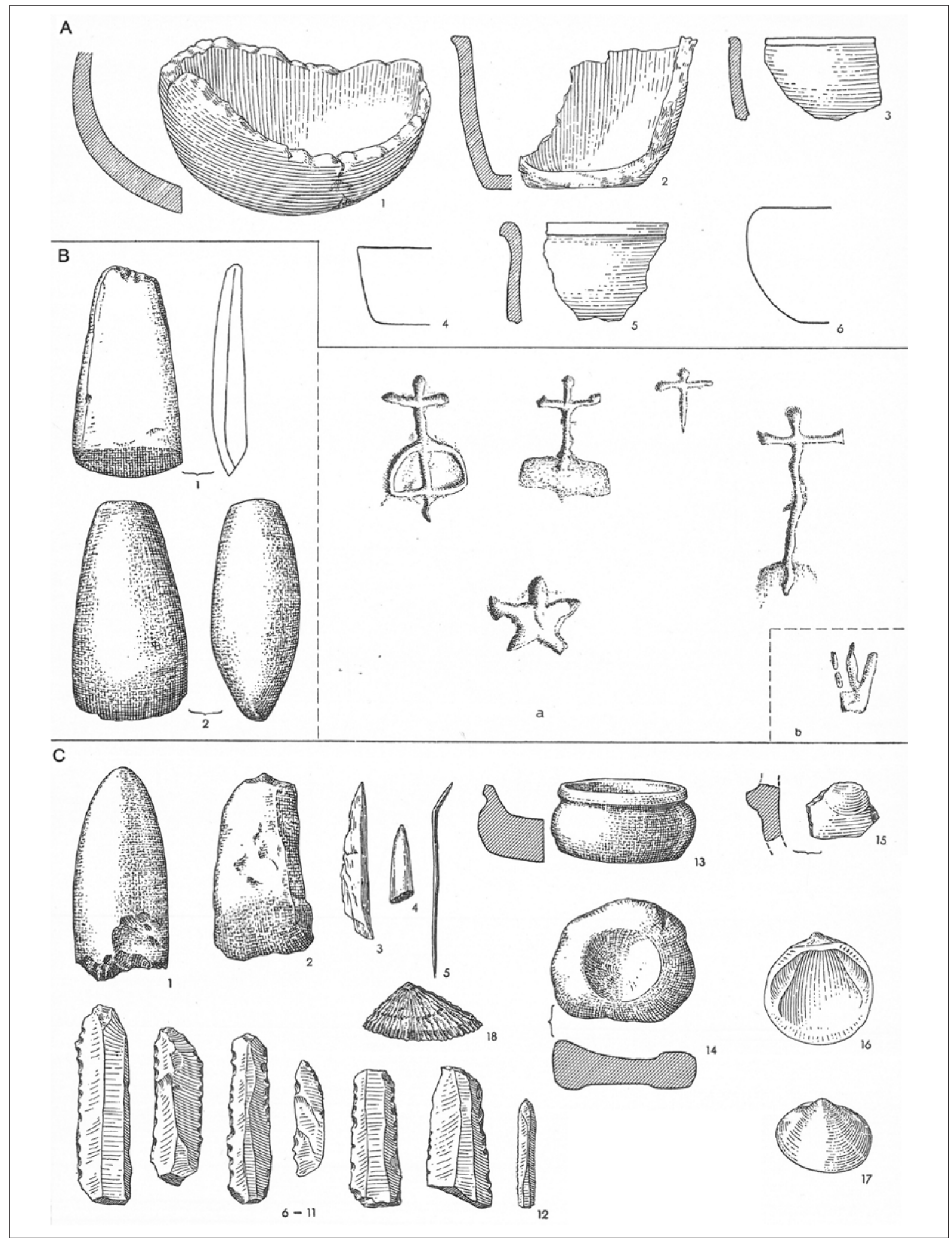

Figure 4. A: El Romeral. Finds. B: Menga. Finds and engravings. C: Viera. Finds (After Leisner and Leisner, 1943: Plate: 58.1-3). 


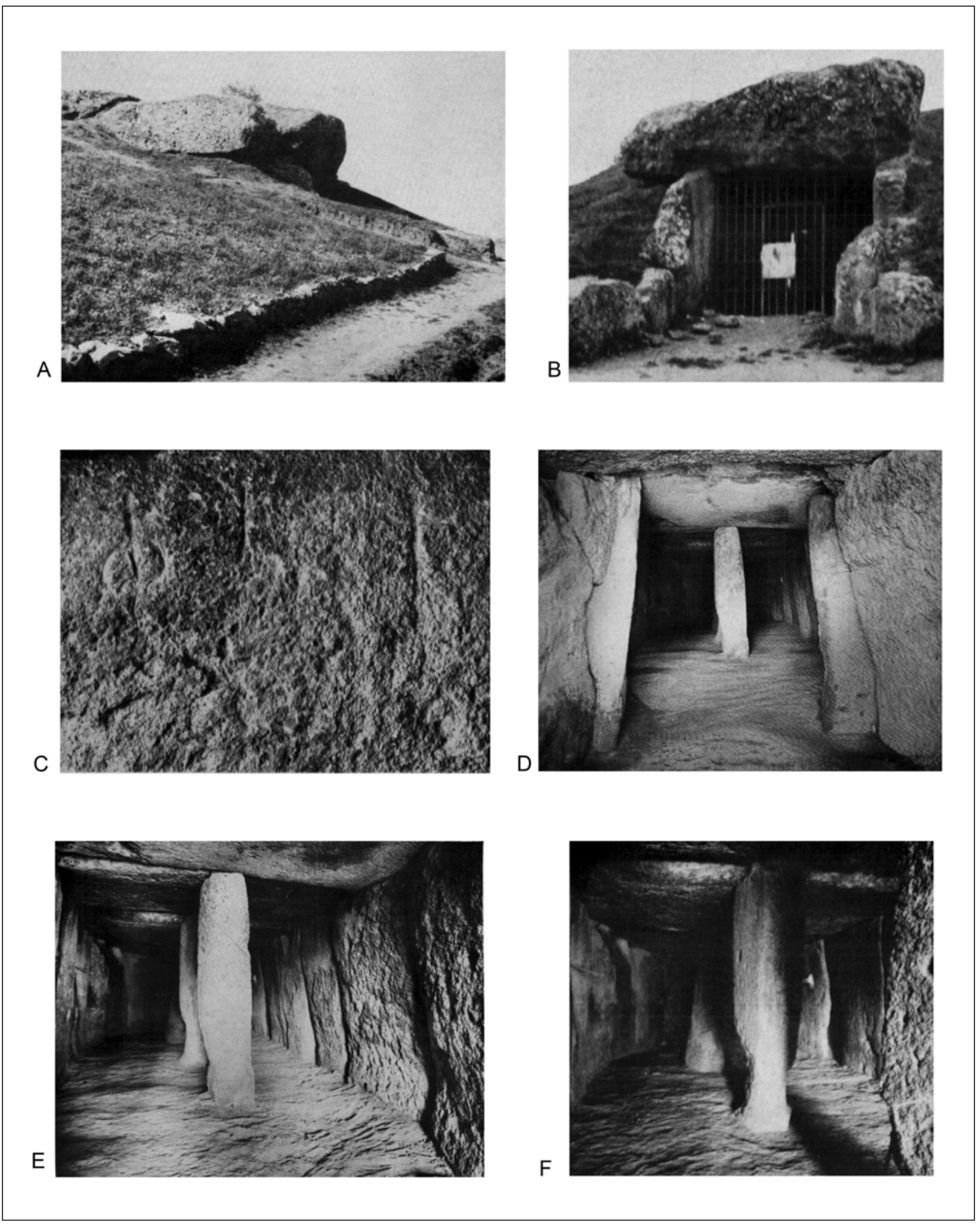

Figure 5. A: Menga, entrance (Leisner and Leisner, 1943: Plate: 98.4). B: Menga, entrance (Leisner and Leisner, 1943: Plate: 105.1). C: Engravings. Menga (Leisner and Leisner, 1943: Plate: 140). D: Menga. Entrance to the main chamber (Leisner and Leisner, 1943: Plate: 104.2). E: Menga. Main chamber with three pillars (Leisner and Leisner, 1943: Plate: 104.1). F: Menga, middle pillar (Leisner and Leisner, 1943: Plate: 105.2). 


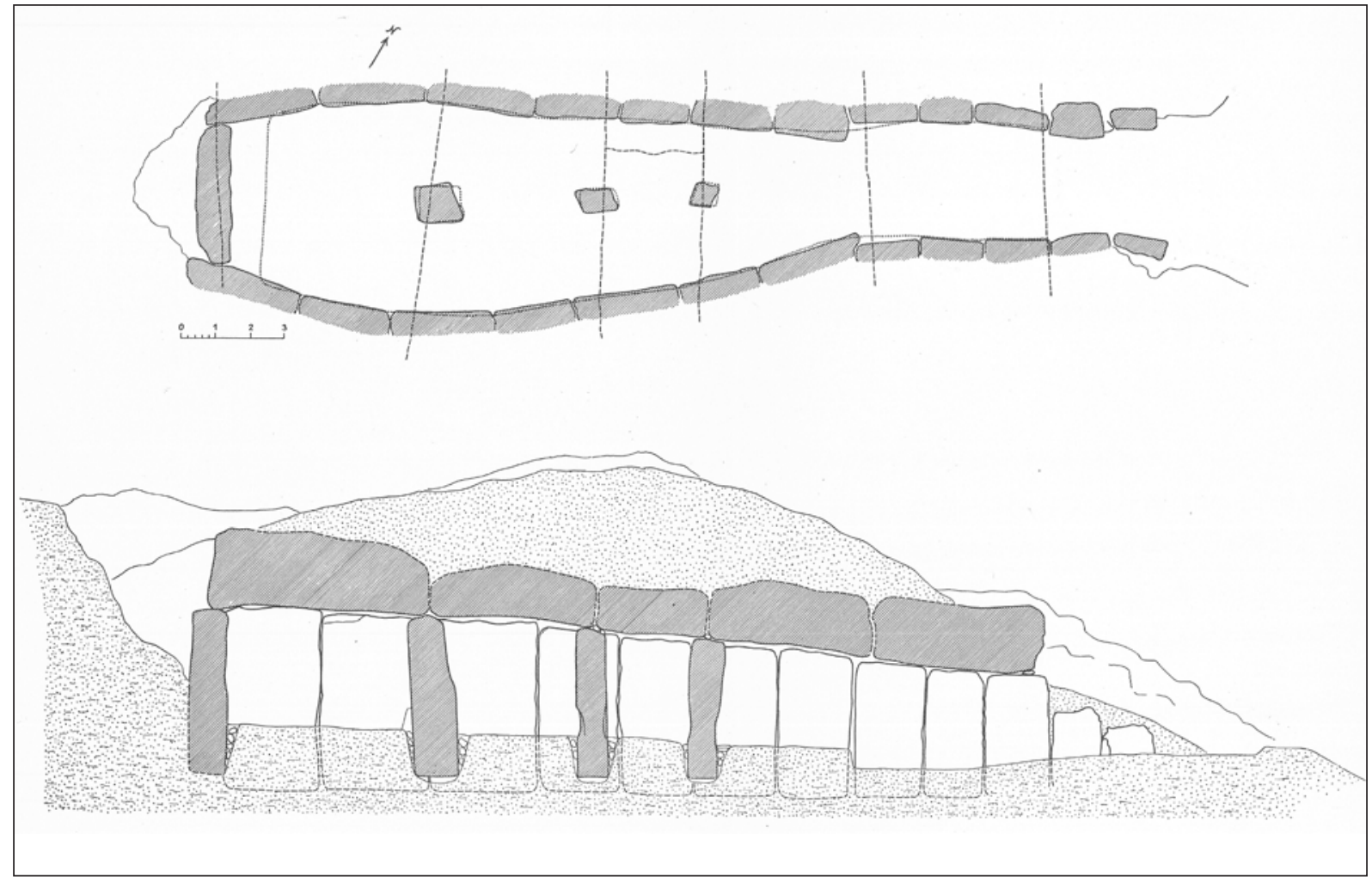

Figure 6. Plan and section of Menga (Leisner and Leisner, 1943: Plate: 56).

In his report of the restoration work undertaken in all three monuments in 1940 (only seven years after the visit by the Leisners), Giménez Reyna did mention that there was a two-metre deep open trench in El Romeral's mound, although he provided no further details about it (Giménez Reyna 1946: 33). It is not unlikely that he himself ordered that trench to be backfilled. No other information has ever been found regarding those trenches, part of what seems an archaeological intervention carried out at some point between 1904 and 1933 and of which no records exist.

It is likely that the «features of black soil» mentioned by the Leisners as proof of the artificial character of the mound, are connected to reuses of the monument at some point in its biography. Pits fitting the Leisners's description («features of black soil and organic remains mixed with sand, mud and pebbles were found», Leisner and Leisner 1943: 174) have been found at sites dated to the $4^{\text {th }}$ and $3^{\text {rd }}$ millennia BC throughout the Antequera region (García Sanjuán et al. 2016). Similarly, despite its obvious intrinsic interest, no evidence is available to this date to interpret the reference made by Pierre Paris (1921: 22-23), and referred to by the Leisners, about the presence of «some kind of gallery that descends steeply and does not lead to a chamber» (Leisner and Leisner 1943: 174) on the northern area of El Romeral mound. In fact, when a Ground Penetrating Radar (GPR) survey of El Romeral was undertaken some 10 years ago (Peña Ruano and Teixidó Ulloa 2009), a feature not entirely incompatible with that described by the Leisners was found. This feature was described as follows: "a linear anomaly shaped as an $S$ and extending vertically to some depth around the small chamber (...) perhaps a gallery» (Peña Ruano and Teixidó Ulloa 2009: 178). The authors of the GPR survey were probably unaware of the reference made by the Leisners seventy years earlier, as they did not link both observations. Even today, almost ninety years later, no accurate information is available about the nature of these features in the mound of El Romeral.

Five equally interesting points were made regarding the architecture of the large tholos. Firstly, concerning the large chamber, the Leisners state that «at 


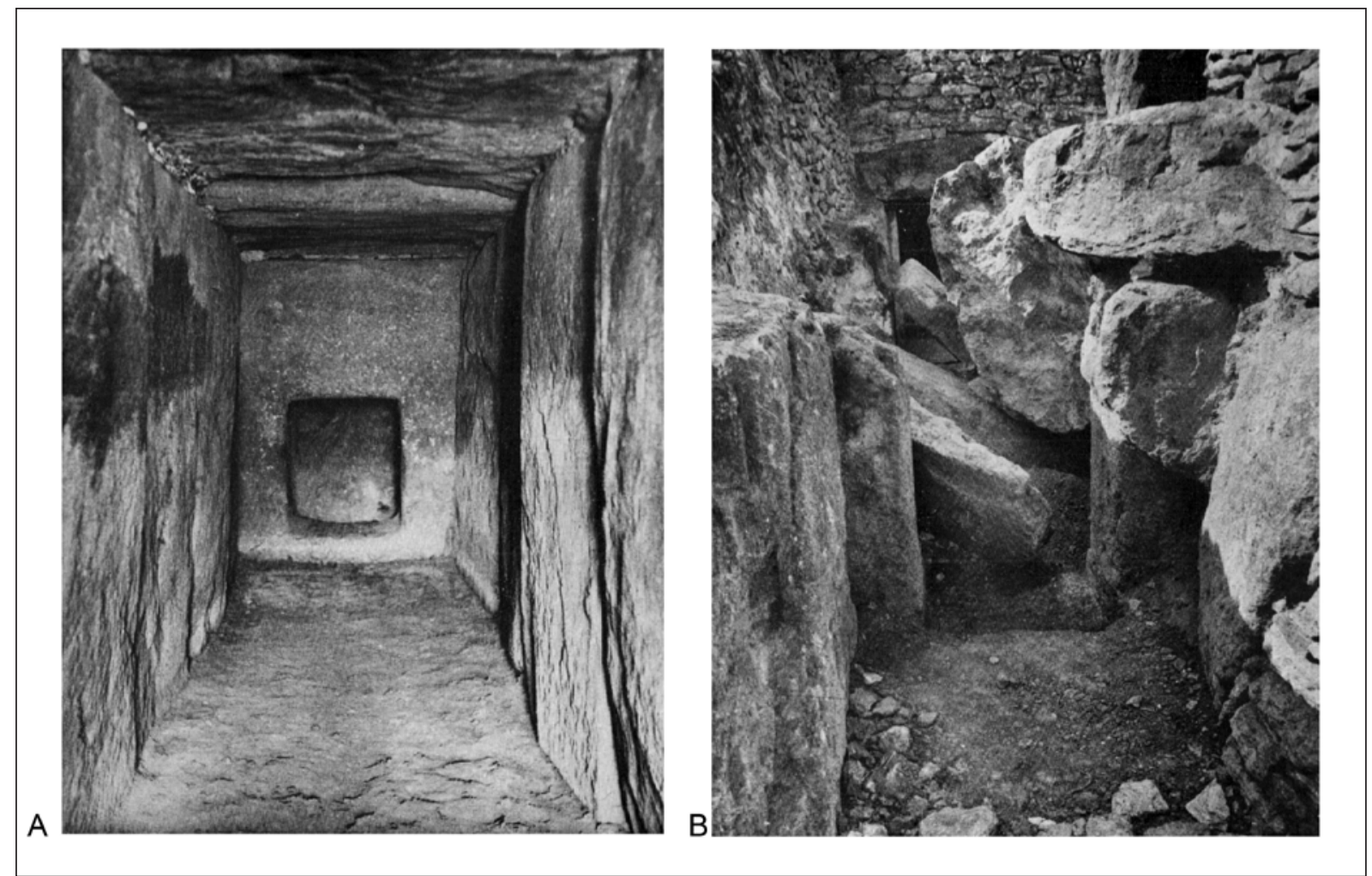

Figure 7. Viera. A: Gate to the chamber as seen from the passage; B. Carved portal in the passage. (Leisner and Leisner, 1943: Plate: 106).

a point, $0.65 \mathrm{~m}$ behind the front wall we discovered $a$ second circular wall. Here, the slabs were also embedded in clay in layers matching the thickness of the slabs» (Leisner and Leisner 1943: 176). To this date, nothing is known about this feature. Unfortunately, no thorough architectural and geotechnical study like the one available for Menga - see for example Carrión Méndez et al. 2009; Lozano et al. 2014 - has been carried out for El Romeral, which imposes a sharp limitation in the understanding of this monument. Secondly, the reference to the "outer antechamber" of the tholos, already disappeared when the Leisners visited it, and which they described on the basis of the accounts and plans published by Velázquez Bosco and GómezMoreno Martínez, is also most relevant. Future excavations will most probably provide evidence concerning this feature. A third remarkable observation about the architecture of El Romeral concerns the paved floor of the main passage and large chamber, made with slabs of various sizes fitting together and small gravel filling the interstices. This floor was recorded and described by Giménez Reyna, who in the 1940s decided to leave it untouched and exposed (Giménez Reyna 1946: 33).
Unfortunately, most of this paved floor seems to have been dismantled in 2002, when aggressive work, of which no published record exists, was undertaken inside the monument. Only a small portion of this floor was left inside the main chamber, on its right side (as one enters) (AAVV 2011: 49 and 151) and there it is visible today. Fourthly, it is worth noting the description provided by the Leisners of some graphic art inside the small chamber («some incised lines, of which a triangle with a central line, crossed by another transversal line, seems to be artificial» (Leisner and Leisner 1943: 176)) as well as coating on the stones forming the jambs of the gate leading into the main chamber, which was also mentioned by Giménez Reyna (1968: 31). These elements are currently awaiting study as part of the on-going research concerning the graphic art of the Antequera megaliths (Bueno Ramírez et al. 2009; 2017; forthcoming). Lastly, the Leisners published a photograph (Leisner and Leisner, 1943: Plate 100.1) [fig 2. G] that shows the remains of a masonry wall laid perpendicularly to the short passage connecting both chambers. As far as it is possible to see from the photograph, this wall collapsed when 


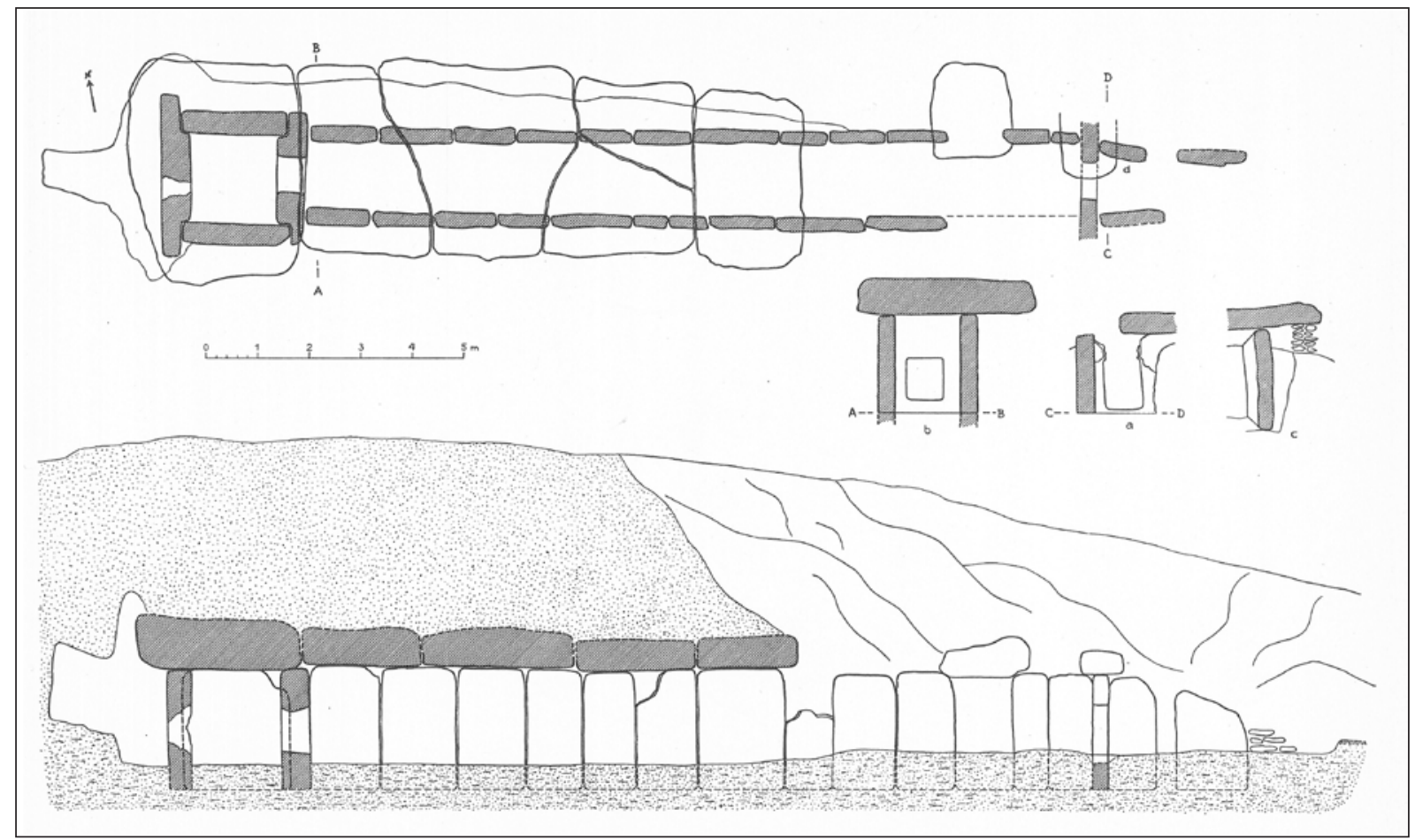

Figure 8. Plan and section of Viera (Leisner and Leisner, 1943: Plate: 57).

the Leisners visited the monument, but at some point in its biography it must have sealed the access to the smaller chamber.

In general, all the observations made by the Leisners concerning El Romeral point at issues that still remain major topics of scientific interest. This highlights what essentially is a generalised lack of information about the architecture, biography and material culture of this great monument.

\subsubsection{Viera}

The Leisners also made some very valuable observations about Viera. Some of them are still awaiting a thorough scientific investigation. For example, that is the case with the highly original architectural device present between the upper edge of the uprights and the lower face of the capstones of this dolmen. The Leisners could not fail to detect such an unusual arrangement: "The capstones do not touch the uprights directly as between them there is a thin layer of slate slabs partly held together with mud. This particular element is also found in the chamber» (Leisner and Leisner 1943: 183). As part of a recent attempt to date the construction of the Antequera monuments through Optically Stimulated Luminescence (OSL), a sample of the material agglutinating the small slate slabs between the uprights and the capstones (which the Leisners described as "mud") was analysed, yielding unfruitful results (Athanassas et al. 2016: 161, fig. 1b). The fact that this feature was visible in the early 1930s proves beyond doubt that it is an integral part of the original design of the monument and not something added as part of the various restoration works this dolmen has undergone since the 1980s - see Fernández Rodríguez et al. 2006; Fernández Rodríguez 2009. The primary function of this remarkable device has not been satisfactorily established yet, but an interesting hypothesis is that it was conceived as a "suspension" system to protect the structure against earthquakes - Antequera is located in the most seismic region of the Iberian Peninsula. A possible connection between these natural phenomena and the prehistoric monuments has been suggested (Bradley and García Sanjuán 2017). Further attempts to characterise and OSL-date this feature will be made shortly.

Another significant contribution to the study of Viera made by the German couple was the discovery of the portal-slab in the passage, which had remained unnoticed up until their visit. This discovery was mentioned by W. J. Hemp in a paper published at around 
the same time (Hemp, 1934: 409). The same can be said of the reference to a paved floor made of thin stone slabs in Viera's passage: «Originally it was paved with thin slabs. According to Santos Rocha, who uses a report by F. Francesco y Lozano, between the pavement and the rock there was a layer of earth...» (Leisner and Leisner 1943: 183). It is unclear to us what the sources of this information were. On October 9 1905, Antonio de Santos Rocha (1853-1901), a Portuguese archaeologist, wrote a letter to Jorge Bonsor (1855-1930), one of the leading figures of Spanish archaeology between the end of the $19^{\text {th }}$ and beginning of the $20^{\text {th }}$ century, to accompany what he described as «the work I have written about the Antequera sepulchres» (Maier Allende 1999: 78). In a second letter to Bonsor, dated November $5^{\text {th }} 1905$, Santos Rocha claims that he is aware of the "new" Antequera dolmens «thanks to a communication by Señor Francisco de Sales Franco y Loxana, from Badajoz, to the Society [Archaeological] and I believe that both you and Señor Moreno are wrong about the origin of the form...» (Maier Allende 1999: $80)$. The Leisners must have been aware of said publication by Santos Rocha, which we have been unable to consult. The person the Leisners call "F. Francesco y Lozano" could well be Francisco de Sales Franco y Loxana, who apparently made the communication that led Santos Rocha to be aware of the discovery of Viera and El Romeral in 1903 and 1904.

Excavations carried out in 1986 and 2003-2004 provided additional evidence of this paved floor (Ferrer Palma 1997a: 129-130; Fernández Rodríguez et al. 2006: 92; Fernández Rodríguez 2009: 65). The Leisners also alluded to the restoration work being undertaken in Viera at the time of their visit, aimed at re-positioning the collapsed stones (Leisner and Leisner 1943: 182) (fig. 7C). This restoration work must have been successfully completed shortly after the Leisners visit, as shown in the photographs published by Hemp one year later (Hemp 1934: pl. LIV, 1-2).

A more intriguing reference comes when the Leisners state that «the capstones protrude from the lateral walls up to $1.70 \mathrm{~m}$, and therefore in all cases they rest on the natural bedrock. Between the upper edge of the ditch cut in the rock and the capstones there is a wall with layers of clay and slabs》 (Leisner and Leisner 1943: 183). This reference to "a wall with layers of clay and slabs" seems slightly confusing, unless the Leisners meant the building system of Viera's mound itself, which was used following the same technique employed in Menga (see below). It seems that the information available in the early 1930 s concerning the construction system of both mounds was ambiguous, and the Leisners did not manage to provide a precise definition of their nature. Nevertheless, the measurements of the mound provided by them $(35 \mathrm{~m}$ across and $4 \mathrm{~m}$ in height) are of the greatest interest, given that after the 2003-2004 restoration work of this monument, its mound was significantly enlarged to $52 \mathrm{~m}$ in the north-south axis, $62 \mathrm{~m}$ in the east-west axis, and 4,5 $\mathrm{m}$ of height (Villalón Conejo 2001) in what constitutes another of the various unnecessarily aggressive restorations carried out in the Antequera megaliths.

\subsubsection{Menga}

In general, the description of Menga's architecture by the Leisners is precise, intuitive and thought-provoking. Regarding the shape of the inner space in this monument, they noticed that the left (southern) side was more curved than the right (northern) one, something confirmed by the geotechnical study undertaken between 2005 and 2006 (Lozano et al. 2014: 767). They also noted the arrangement of the pillars along the dolmen's longitudinal axis, their precise placement under the joints of the capstones as well as the presence of an infill of smaller stone and coating on top of pillars 1 and 2, which they interpreted as a device aimed at reinforcing the weight-supporting role of the pillars - the same conclusion was later reached by the geotechnical analysis (Carrión Méndez et al. 2009: 158). They also noted the smooth regularity and precise adjoining of the uprights, which did not demand the use of smaller masonry, and their slight leaning inwards (except for the backstone, which is totally straight). Again, these features, defining Menga as a true masterpiece of megalithic architecture, were later highlighted in the geotechnical analysis (Lozano et al. 2014: 767).

The Leisners did also mention that the pillars may have been originally coated with plaster and perhaps decorated with painted motifs. The presence of graphic art in Menga has been thoroughly examined in recent years (Bueno Ramírez et al. 2008; 2009; 2017). Recent studies of the engraved motifs visible on the fourth upright of the left (southern) side suggest that, contrary to what the Leisners thought, only one of the motifs is an anthropomorphic one (of the schematic rock art type) likely to belong to the original design of the monument, although it was later "Christianised" to make it match with the other three crosses engraved next to it (Bueno Ramírez et al. 2009: 195), the last motif being a sun (Bueno Ramírez et al. 2004: 52). 
There are various other points in the Leisners's description of Menga that deserve some comment. For example, they claimed that Menga's orientation was $30^{\circ}$, which has later been proven wrong, as precise calculations show that the monument's line of axial symmetry «is directed towards an azimuth (angle from true North) of $45^{\circ}$, half way between north and east》 (Hoskin 2009: 182) - this orientation, outside the range of sunrise, does not preclude the fact that sunlight may have played a major role in the design of the monument and the "scenography" used as part of the ceremonies held in it (Lozano et al. 2014). The orientations provided by the German couple for Viera and El Romeral, to $96^{\circ}$ and $199^{\circ}$ respectively, were later corrected too (Hoskin 2009).

The Leisners also highlighted the presence of a groove running on the lower face of the capstones. Following De Mergelina, who had already noticed this feature, the Leisners suggest that it could have served as a "guide" for the installation of the capstones when the dolmen was built. Although briefly discussed by Giménez Reyna (1946: 40) this interesting idea has not been examined as part of the geoarchaeological and geotechnical studies of Menga undertaken in recent years (Carrión Méndez et al. 2009; Lozano et al. 2014). In his report of the restoration carried out in the late 1990s, Espinosa Gaitán (1998: 82) interpreted these grooves as resulting from a loss of materiality in the contact surfaces between the uprights and the capstones.

Other elements in the description of the Leisners are more ambiguous. That seems to be the case when they point out that in Menga, «The upper right corner of the backstone has an aperture of approximately one square metre, probably made by looters who may have easily entered here through the mound» (Leisner and Leisner 1943: 178). This aperture through the backstone was made by Rafael Mitjana y Ardison in order to have light while he worked inside the monument. Their description of Menga's mound is also slightly confusing, as they affirmed that «...the burial construction is embedded in a natural hill» (Leisner and Leisner 1943: 179), which seems to imply that a natural hill was used to embed the megalith, like is the case for example at La Pastora or Montelirio at the Copper Age mega-site of Valencina de la Concepción-Castilleja de Guzmán. Later, however, they claim that «the remains of the mound, preserved over the chamber to $3.0 \mathrm{~m}$, flattened at the top, are also composed of clay and layers of stones》 (Leisner and Leisner 1943: 179), which, instead, seems to suggest a fully artificial mound. The Leisners never made an explicit statement on this point. Both interventions by the universities of Malaga and Granada proved that Menga's mound is fully artificial, and was built with alternating layers of packed clay and stones - see for example Ferrer Palma et al. 2004: 187-192.

More anecdotal, but still valuable all the same, is the discussion made by the German authors concerning the controversial subject of Menga's name. On this issue, the Leisners favoured the theory, already mentioned in earlier publications, linking the name to a legendary "giant": «To this date, the origin of the Menga name (Mengal?) is unclear. Of the various conjectures, only one seems to be well grounded, which connects it with an old gypsy song linked with the Baena menhir, and in both is connected with legends about a giant» (Assas y Ereño 1857: 130). A recent analysis by a specialist in archaeological toponymy, however, suggests the toponym is connected to the Latin name Dominica so that "Cova Dominica" would have evolved into "Cova Dominga", and later "Cueva de Menga" just as the Spanish "Domingo" is the Latin equivalent of "Dominicus" ("lord") (Ruhstaller 2017). This interpretation makes sense within the general context of the Neolithic world-view, which as it is generally accepted was presided over by the idea of a nature as a "mother" or "lady", and very especially in the case of Menga, where the dolmen is strongly connected to water, a most prominent natural element, through a well located at the back of the chamber.

\section{CONCLUSIONS}

Throughout their careers, Georg and Vera Leisner centred their research on the architectural analysis of megalithic monuments and the material culture associated to them. They developed a systematic method of research based on direct observation, drawing and photographing, coupled with the discussion of available sources. Over several decades, they visited, studied and described hundreds of megalithic monuments throughout Spain and Portugal, compiling all the information in two highly systematised corpora that to this date are an unabiding reference to any research on this field.

This is not less true in the case of the Antequera monuments. Their work on this site, based on the visit they made in February 1933 (Leisner and Leisner 1943: 182, 184) or 1934 (Leisner 1941: 115), represented a substantial advancement which included a detailed description of each monument and their discussion on the basis of their own examination and the available literature. One of the reasons why the work of the Leisners at Antequera is so important is because no other similarly-detailed 
description of these monuments would be made for more than fifty years. Not even the ambitious project carried out in the late 1980s and 1990s, which involved extensive excavations of Menga and Viera, managed to provide descriptions of the monuments that could match those made by the German couple. The Leisners's description is also important because it signals a number of research themes that, in some cases, still remain unsolved. The problem of the form, architecture and biography of El Romeral, and specially its gigantic mound, has not been addressed yet. The same applies to some of the highly original architectural devices identified in Viera which, although tentatively addressed, have not been satisfactorily solved yet.

Of course, recent research has achieved relevant advances - at least for Menga and Viera. Today we know a lot more about the temporality and the biography of these monuments than back in the 1930s. Research on the megalithic phenomenon world-wide has also made important strides towards understanding the social and cultural significance of these constructions. In this sense, some of the most basic assumptions the work of the Leisners was based on are probably not valid today. For example, the Leisners always referred to the Antequera megaliths as "graves" ("Gräber"). In fact, this has been a common denominator for all research on these monuments throughout the $20^{\text {th }}$ century - the publications of the Malaga University team also used this term (cf. Ferrer Palma 1997a; 1997b; Ferrer Palma et al. 2004; Marqués Merelo et al. 2004a; 2004b). This terminology has been respected in both the translations presented as part of this paper. But it is important to note that the conclusions of the research carried out in the last decade have helped to establish conclusively that the concept of "grave" or "sepulchre" applied to these constructions is excessively reductionist. Even though we have little direct evidence to go by, given the strong significance that the cult of the ancestors had in the ideology of Neolithic and Chalcolithic societies, it is unlikely that the use of Menga, Viera or El Romeral as sanctuaries or temples did not involve, from the earliest stages, a connection with death - perhaps through the deposition and/or manipulation of human remains of certain individuals of especial social importance. But at the same time, to reduce these monuments to a role as "tombs" is an over-simplification. There are several elements in their design (which must have demanded the participation of the best engineers and architects of their time) that show the important role they played as materialisations of the world view of Neolithic societies. In Menga, that is the case with the axial orientation or the water well. These magnificent megalithic monuments were at the centre of the social action of their time, and it is very likely that they acted of foci of attraction for people living not only locally but further afield. As such, they helped to establish and perpetuate the social and ideological order of their times, which made them much more than just "graves". And then there is also the recently gathered evidence of their remarkably long biographies, particularly in the case of Menga (García Sanjuán et al. 2018). It is hard to imagine how a construction conceived just as a "tomb" would have had the cultural weight to be a persistent focus of social life for almost six thousand years.

To conclude, it must be said that despite all recent advances, whether empirical or theoretical, the work of the Leisners still embodies a true program of future research for the Antequera megaliths. This can be acknowledged even from today's perspective, as has been illustrated throughout this paper with several examples. We hope this paper contributes to make justice to what in fact was one of the most important contributions to the study of the Antequera megaliths in the $20^{\text {th }}$ century. We also hope that the two translations that accompany this paper will contribute to make sure that the work of the Leisners remains a major reference for future research work at this great prehistoric site.

\section{Acknowledgments}

This study has been funded by the project "Nature, Society and Monumentality: High Resolution Archaeological Investigations on the Megalithic Landscape of Antequera" (HAR2013-45149-P) (2014-2017), sponsored within the National R\&D Plan of the Ministry of Economy and Competitiveness (Spanish Government). This study was undertaken as part of the project "Societies, Territories and Landscapes in the Prehistory of Antequera (Malaga)" (2013-2018), approved by the Ministry of Culture of the Andalusian Government. We would like to thank Lucy Shaw Evangelista for her kind revision of the English translation of the text and various suggestions as to its writing.

\section{REFERENCES}

AA.VV. (2011): El Conjunto Arqueológico Dólmenes de Antequera. Documento de Avance del Plan Director. Tomo III. Institucionalización. Sevilla, Junta de Andalucía. 
Almagro Basch, M. (1958): "Necrología. Georg Leisner (1870-1957)". Ampurias 19-20: 294-295.

Amador de los Ríos, R. (1907): Catálogo de los Monumentos Históricos y Artísticos de la Provincia de Málaga. Málaga, Cánovas del Castillo Library.

Aranda Jiménez, G.; García Sanjuán, L.; Mora Molina, C.; Moreno Escobar, M. C.; Riquelme Cantal, J. A.; Robles Carrasco, S. and Vázquez Paz, J. (2015): "Evidencias de asentamiento y prácticas funerarias en los dólmenes de Menga y Viera en la Antigüedad: la intervención de 1988". Menga. Revista de Prehistoria de Andalucía 06: 253-280.

Assas y Ereño, M. (1857): "Monumentos célticos". Semanario Pintoresco Español, 17: 130-133.

Athanassas, C.; García Sanjuán, L.; Theodorakopoulou, K.; Jain, M.; Sohbati, R.; Guerin, G. and Lozano Rodríguez, J. A. (2016): "Testing the potential of Optically Stimulated Luminescence (OSL) for the dating of the Antequera megaliths (Málaga, Spain): assessing the results of the first round of sampling". Menga: Revista de Prehistoria de Andalucía 7: 157-164.

Baceiredo Rodríguez, V.; Baceiredo Rodríguez, D.; García Sanjuán, L. and Odriozola Lloret, C. P. (2014): "Planimetría de alta resolución del dolmen de Menga (Antequera, Málaga) mediante escaneado láser terrestre, levantamiento 3D y fotogrametría". Menga. Revista de Prehistoria de Andalucía 05: 259-269.

Bellón Ruiz, J. P. (2010): “De arquitectura tartesia: los dólmenes de Antequera en el contexto de la obra de Manuel Gómez-Moreno Martínez". Menga. Revista de Prehistoria de Andalucía 1: 115-134.

Benavides López, J. A.; Esquivel Sánchez, F. J. and Esquivel Guerrero, J. A. (2015): "Nuevas aportaciones al estudio métrico y geométrico del dolmen de Viera (Antequera, Andalucía)". Menga. Revista de Prehistoria de Andalucía 6: 201-210.

Blech, M. (2009): “Leisner, Georg”, in M. Díaz-Andreu, G. Mora y J. Cortadella (eds.), Diccionario Histórico de la Arqueología en España (Siglos XV$X X)$ : 343. Madrid, Marcial Pons.

Boaventura, R. (2017): “VERA.LEISNER@PORTUGAL.PT". Ophiussa 1: 131-142.

Boaventura, R. and Langley, M. (2007): “Georg Leisner (1870-1957): Determinação na busca do megalitismo iberico". O Arqueólogo Português $4^{\mathrm{a}}$ serie, 25: 167-176.

Boaventura, R. and Langley, M. (2011): "Matrimónio Leisner: a pretexto do seu centenário, o episódio de Coimbra". O Arqueólogo Português $5^{\mathrm{a}}$ série, 1: 301-311.
Bradley, R. and García Sanjuán, L. (2017): "Sudden Time? Natural disasters as a stimulus to monument building: From Silbury Hill (Great Britain) to Antequera (Spain)", in P. Bickle, V. Cummings, D. Hofmann and J. Pollard (eds.), Neolithic Europe: Essays in Honour of Professor Alasdair Whittle: 181-201. Oxford, Oxbow Books.

Bueno Ramírez, P.; De Balbín Behrmann, R. and Barroso Bermejo, R. (2004): “Arte megalítico en Andalucía: una propuesta para su valoración global en el ámbito de las grafías de los conjuntos productores del sur de Europa". Mainake 26: 29-62.

Bueno Ramírez, P.; De Balbín Behrmann, R. and Barroso Bermejo, R. (2008): "Dioses y antepasados que salen de las piedras", in L. García Sanjuán (ed.), Patrimonio Megalítico: Más Allá de los Límites de la Prehistoria. PH Boletín del Instituto Andaluz del Patrimonio Histórico, Monográfico 67: 4661. Sevilla, Junta de Andalucía

Bueno Ramírez, P.; De Balbín Behrmann, R. and Barroso Bermejo, R. (2009): “Análisis de las grafías megalíticas de los dólmenes de Antequera y su entorno", in B. Ruiz González (ed.), Dólmenes de Antequera. Tutela y Valorización Hoy: 186-197. Sevilla, Junta de Andalucía.

Bueno Ramírez, P.; De Balbín Behrmann, R. and Barroso Bermejo, R. (2017): "Steles, Time and Ancestor in the Megaliths of Antequera, Málaga (Spain)". Menga. Revista de Prehistoria de Andalucía 08: 193-219.

Bueno Ramírez, P.; De Balbín Behrmann, R. and Barroso Bermejo, R. (forthcoming): "Estudio de las grafías de Viera y El Romeral (Antequera, Málaga): Campaña de 2017". Anuario Arqueológico de Andalucía 2017. Sevilla, Junta de Andalucía.

Burkitt, M. C. (1926): Our Early Ancestors. An Introductory Study of Mesolithic, Neolithic and Copper Age Cultures in Europe and Adjacent Regions. Cambridge, Cambridge University Press.

Carrión Méndez, F.; Lozano Rodríguez, J. A.; García González, D., Muñiz López, T.; Félix, P.; López Rodríguez, C. F.; Esquivel Guerrero, J. A. and Mellado García, I. (2009): "Estudio geoarqueológico de los dólmenes de Antequera", in B. Ruiz González (ed.), Dólmenes de Antequera. Tutela y Valorización Hoy: 144-163. Sevilla, Junta de Andalucía.

Cerdán Márquez, C.; Leisner, G. and Leisner, V. (1952): Los Sepulcros Megalíticos de Huelva. Excavaciones Arqueológicas del Plan Nacional 1946. Informes y Memorias de la Comisaría General de Excavaciones Arqueológicas 26. Madrid, Ministerio de Educación Nacional. 
Daniel, G. E. (1973): "Spain and the problem of European megalithic origins", en Estudios Dedicados al Profesor Dr. Luis Pericot: 209-214. Barcelona, Universidad de Barcelona.

De Mergelina, C. (1922): "La necropoli tartesia de Antequera”. Sociedad Española de Antropología, Etnografía y Prehistoria. Actas y Memorias Año I, Tomo I, Cuaderno I, Memoria IV, $3^{\text {a }}$ Sección: 37-90.

De Mortillet, A. (1921): "Le Dolmen d'Antequera", en L'Avancement des Sciences fusionnée avec L'Association Scientifique de France. Compte Rendu de la 44 Session: 475-480. Strasbourg, Association Scientifique de France.

Do Paço, A.; Leisner, V.; Trindade, L. and Schubart, H. (1964): "Castro do Zambujal (Torres Vedras)". Boletín Cultural da Junta Distrital de Lisboa, II Serie 61-62: 279-306.

Espinosa Gaitán, J. (1998): “Estudio petrográfico de los materiales de los dólmenes de Antequera". $\mathrm{PH} \mathrm{Bo}$ letín 25: 80-88.

Fernández Rodríguez, L. E. (2009): “La interacción entre los proyectos de restauración de estructuras y la investigación arqueológica: el caso del sepulcro megalítico de la Cueva de Viera". Caetaria. Revista Bianual de Arqueología 6-7: 61-74.

Fernández Rodríguez, L. E.; Romero Pérez, M. and Ruiz De La Linde, R. (2006): "Resultados preliminares del control arqueológico de los trabajos de consolidación del sepulcro megalítico de Viera, Antequera". Anuario Arqueológico de Andalucía/2003, Tomo III. Actividades de Urgencia: 8999. Sevilla, Junta de Andalucía.

Ferrer Palma, J. E. (1997a): "Proyecto de reconstrucción arquitectónica y paleoambiental en la necrópolis megalítica de Antequera (1985-1991): aspectos metodológicos", in J. Martín Ruiz, J. A. Martín Ruiz and P. J. Sánchez Bandera (eds.), Arqueología a la Carta. Relaciones Entre Teoría y Método en la Práctica Arqueológica: 119-144. Málaga, Diputación Provincial de Málaga.

Ferrer Palma, J. E. (1997b): "La necrópolis megalítica de Antequera. Proceso de recuperación arqueológica de un paisaje holocénico en los alrededores de Antequera, Málaga". Baetica 19: 351-370.

Ferrer Palma, J. E.; Marqués Merelo, I.; Baldomero Navarro, A. and Aguado Mancha, T. (2004): "Estructuras tumulares y procesos de construcción en los sepulcros megalíticos de la provincia de Málaga: la necrópolis megalítica de Antequera". Mainake. Estudios de Arqueología Malagueña 26. Monográfico
Los Enterramientos en la Península Ibérica durante la Prehistoria Reciente: 117-210.

García Sanjuán, L. (2009): "Criterios para un Programa de Investigación. Sociedades, territorios y paisajes en la Prehistoria de Antequera", in B. Ruiz González (ed.), Dólmenes de Antequera. Tutela y Valorización Hoy: 112-127. Sevilla, Junta de Andalucía.

García Sanjuán, L. and Mora Molina, C. (eds.) (2018): La Intervención de 2005 en el Dolmen de Menga. Temporalidad, Biografia y Cultura Material en un Monumento del Patrimonio Mundial. Sevilla, Junta de Andalucía y Universidad de Sevilla.

García Sanjuán, L.; Mora Molina, C. and Lozano Rodríguez, J. A. (2018): "Valoración y conclusiones. Cultura material, tiempo y persistencia en la biografía del dolmen de Menga", in L. García Sanjuán and C. Mora Molina (eds.), La Intervención de 2005 en el Dolmen de Menga. Temporalidad, Biografía y Cultura Material en un Monumento del Patrimonio Mundial: 355-410. Sevilla, Junta de Andalucía y Universidad de Sevilla.

García Sanjuán, L.; Moreno Escobar, M. C.; Márquez Pérez, J. and Wheatley, D. (2016): “The Copper Age in the Lands of Antequera (Málaga, Spain): Introduction to the settlement patterns and social dynamics". Zephyrus 78: 35-65. http://dx.doi. org/10.14201/zephyrus2016783565

Germond de Lavigne, A. (1866): Itinéraire Descriptif, Historique et Artistique de l'Espagne et du Portugal. Paris, Hachette.

Giménez Reyna, S. (1946): Memoria Arqueológica de la Provincia de Málaga hasta 1946. Informes y Memorias No 12 . Madrid, Ministerio de Educación Nacional. Comisaría General de Excavaciones Arqueológicas.

Giménez Reyna, S. (1968): Los Dólmenes de Antequera. Antequera, Caja de Ahorros y Préstamos de Antequera.

Gómez-Moreno Martínez, M. (1905): “Arquitectura tartesia: la necrópoli de Antequera". Boletín de la Real Academia de la Historia Tomo XLVII (JulioSeptiembre): 81-132.

Hancock, A. M. (1882): "Prehistoric Discoveries in the South of Spain". Transactions of the Anthropological Society of Washington Vol. 1: 66-68.

Harlé, E. (1887): "Le dolmen de Antequera". Matériaux pour l'histoire primitive et naturelle de l'homme. Revue Mensuelle Illustrée, XXI Année, $3^{\mathrm{a}}$ Série, Tome IV: 80-82.

Hemp, W. J. (1934): “The Passages Graves of Antequera, and Maes Howe, Orkey". The Antiquaries Journal 14(4): 404-413. 
Hoskin, M. (2009): "La arqueoastronomía de Antequera”, in B. Ruiz González (ed.), Dólmenes de Antequera. Tutela y Valorización Hoy: 180-185. Sevilla, Junta de Andalucía.

Leeds, T. E. (1921): "VII. The Dolmens and Megalithic Tombs of Spain and Portugal". Archaeologia 70: 201-232.

Leisner, G. (1941): "Puertas perforadas en sepulcros megalíticos de la Península Hispánica”. Corona de Estudios que la Sociedad Española de Antropología, Etnografía y Prehistoria dedica a sus Mártires, Tomo I: 107-124.

Leisner, V. (1965): Die Megalithgräber der Iberischen Halbinsel. Der Westen. Collection Madrider Forschungen 1:3. Berlin, Gruyter.

Leisner, V. (1967): “Die verschiedenen Phasen des Neolitikums in Portugal". Palaeohistoria 12: 363-372.

Leisner, G. and Leisner, V. (1943): Die Megalithgräber der Iberischen Halbinsel. Erster Teil: Der Süden. Collection Römisch-Germanische Forschungen, 17. Berlin, Verlag Von Walter de Gruyter und Co.

Leisner, G. and Leisner, V. (1951): Antas do Concelho de Reguengos de Monsaraz. Materiais para o Estudo da Cultura Megalítica em Portugal. Lisboa, Estudos.

Leisner, G. and Leisner, V. (1956): Die Megalithgräber der Iberischen Halbinsel. Der Westen. Collection Madrider Forschungen 1:1. Berlin, Gruyter.

Leisner, G. and Leisner, V. (1959): Die Megalithgräber der Iberischen Halbinsel. Der Westen. Collection Madrider Forschungen 1:2. Berlin, Gruyter.

Leisner, V. and Veiga Ferreira, O. (1963): "Primeiras datas de radiocarbono 14 para a cultura megalitica portuguesa". Revista de Guimarâes 73: 358-366.

Leisner, V. and Ribeiro, L. (1968): "Die dolmen von Carapito". Madrider Mitteilungen 9: 11-62.

Leisner, V.; Zbyszewski, G. and Veiga Ferreira, O. (1969): Les Monuments Préhistoriques de Praia das Maças et de Casainhos. Comunicaçoes dos Serviços Geológicos 16. Lisboa, Serviços Geológicos.

Llobregat, E. A. (1966): "Estudio de los megalitos portugueses por los Leisner y las cuevas de enterramiento múltiple del País Valenciano". Archivo de Prehistoria Levantina 11: 81-90.

Lozano, J. A.; Ruiz-Puertas, G.; Hódar-Correa, M.; Pérez-Valera, F. and Morgado, A. (2014): "Prehistoric engineering and astronomy of the great Menga Dolmen (Málaga, Spain). A geometric and geoarchaeological analysis". Journal of Archaeological Science 41: 759-771. http://dx.doi.org/10.1016/j. jas.2013.10.010
Maier Allende, J. (1999): Epistolario de Jorge Bonsor (1886-1930). Madrid, Real Academia de la Historia.

Marqués Merelo, I.; Ferrer Palma, J. E.; Aguado Mancha, T. and Baldomero Navarro, A. (2004a): "La necrópolis megalítica de Antequera (Málaga): historiografía y actuaciones recientes". Baetica. Estudios de Arte, Geografia e Historia 26: 173-190.

Marqués Merelo, I.; Aguado Mancha, T.; Baldomero Navarro, A. and Ferrer Palma, J. E. (2004b): "Proyectos sobre la Edad del Cobre en Antequera, Málaga", in Actas de los Simposios de Prehistoria de la Cueva de Nerja. La Problemática del Neolítico en Andalucía. Las Primeras Sociedades Metalúrgicas en Andalucía: 238-260. Nerja, Fundación Cueva de Nerja.

Márquez Romero, J. E. and Fernández Ruiz, J. (2009): Dólmenes de Antequera. Guía Oficial del Conjunto Arqueológico. Sevilla, Junta de Andalucía.

Mélida, J. R. (1906): Iberia arqueológica ante romana: discursos leidos ante la Real Academia de la Historia en la recepción pública del ilmo. señor D. José Ramón Mélida el dia 8 de Diciembre de 1906. Madrid, Est. Tip. de la Viuda e Hijos de Tello.

Mitjana y Ardison, R. (1847): Memoria sobre el Templo Druida hallado en las Cercanías de la Ciudad de Antequera. Málaga, Imprenta de D. José Martínez Aguilar.

Moya Morales, J. (2004): Manuel Gómez-Moreno González. Obra Dispersa e Inédita. Granada, Fundación Rodríguez-Acosta.

Obermaier, H. (1919): El Dolmen de Matarrubilla (Sevilla). Junta para la Ampliación de Estudios e Investigaciones Científicas. Comisión de Investigaciones Paleontológicas y Prehistóricas. Memoria número 26. Madrid, Museo Nacional de Ciencias Naturales.

Obermaier, H. (1920): "Die dolmen Spaniens". Mitteilungen der Anthroplogischen Gesellschaft in Wien 50: $107-132$.

Paris, P. (1921): Promenades Archéologiques en Espagne. París, Éditions Ernest Leroux.

Peña Ruano, J. A. and Teixidó Ulloa, T. (2009): “Análisis geofísico de los dólmenes de Antequera”, in B. Ruiz González (ed.), Dólmenes de Antequera. Tutela y Valorización Hoy: 164-179. Sevilla, Junta de Andalucía.

Rojas y Rojas, T. (1861): "La Cueva de Menga". El Museo Universal 37: 295-296.

Ruhstaller, S. (2017): "El origen del nombre Menga". Menga. Revista de Prehistoria de Andalucía 8: 183-192. 
Ruiz González, B. (ed.) (2009): Dólmenes de Antequera. Tutela y Valorización Hoy. Sevilla, Junta de Andalucía.

Sánchez-Cuenca López, J. I. (2011): Menga en el Siglo XIX. El Más Bello y Perfecto de los Dólmenes Conocidos. Menga. Revista de Prehistoria de Andalucía. Monografías no 2. Sevilla, Junta de Andalucía.

Sangmeister, E. (1973): "In memoriam Vera Leisner". Madrider Mitteilungen 14: 247-250.

Sousa, A. C.; Torquato, F.; Bragança, F. and Kunst, M. (2015): “O Arquivo Leisner (Instituto Arqueológico Alemão): o acervo epistolar (1936-1974): os dados e as perspetivas de um projeto em curso". Revista Portuguesa de Arqueologia 18: 267-288.
Talbot, J. (1869): "Notes on Spanish Archaeology". Proceedings of the Royal Irish Academy (1836-1869), Vol. 10 (1866-1869): 474-480, XXXVI y XXXVII.

Tenison, L. (1853): Castile and Andalucia. London, Richard Bentley.

Velázquez Bosco, R. (1905): “Cámaras Sepulcrales descubiertas en término de Antequera". Revista de Archivos, Bibliotecas y Museos 5, 1-7.

Villalón Conejo, A. (2001): Proyecto de Consolidación del Dolmen de Viera. Conjunto Dolménico de Antequera. (Málaga). Proyecto inédito. Antequera, Conjunto Arqueológico de los Dólmenes de Antequera

Wattenbach, W. (1869): Eine Ferienreise nach Spanien und Portugal. Berlín, Verlag von Wilhelm Hertz. 



\section{SUPPLEMENTARY INFORMATION 1}

\author{
IV. Province of Malaga.
}

The famous Antequera dolmens are currently the only ones explored in the province

Group 1. Antequera.

The city of Antequera is located 500 metres above sea level in the rich Guadalhorce valley. The Abdalajís sierra, presenting on its northern side picturesque mountainous landscapes crowned by an ancient fortress (Plate. 97,2) [Figure 1.A], separates the valley from the Malaga coastline. Today, three roads descend towards the coast: one follows the course of the Guadalhorce, the only river that cuts through the Baetic Cordillera, allowing access to the south without crossing it. The other two reach the sea after traversing the sierra, crossing smaller rivers. Thus, Malaga becomes the natural harbour of the Antequera lowlands and it is thought that, just like in Almería, in prehistoric times there may have been interaction between the coast and the mainland. However, unlike the south-east, no trace of coastal settlements has yet been found in Malaga.

The Antequera region owes its wealth to a very productive land and a fairly mild climate, as well as the strategic position as a crossroads between Seville, Granada and Malaga. The railway carrying minerals from Linares to the sea still works nowadays, passing through Antequera towards Malaga, so it is possible that trade was a major factor in the flourishing of Antequera in prehistoric times. Especially because metals are found in the most immediate surroundings. All three enormous megalithic tombs located in the vicinity of the city bear witness to this flourishing, the Cave of Menga, Viera and the Cave of El Romeral, which are counted among the best known and most important of the Iberian Peninsula. And they are probably not the only ones: Mergelina reports other possible artificial hills.

The available literature on the three sepulchres is summarised next, mentioning which tombs are dealt with individually. All authors before 1905 only knew the Cave of Menga. The most important publications are marked by an asterisk.

1. Ancient sources with original reports and plans:

R. Méndez Silva, Población general de España: sus trofeos, blasones y conquistas heroicas (1675).
R. Mitjana, Memoria sobre el templo druida descubierto en la ciudad de Antequera (1847).

C. Lucas, Comptes-rendus de la Soc. Franç. de Numism. et d'Arch. 2, 1870, 277. 319.

E. Harlé, Matériaux pour l'Histoire de l'Homme 1887, 80 .

E. Cartailhac, Les âges prehistoriques de l'Espagne et du Portugal (1886) 186 (Plan by Nodet).

2. New sources with original reports and new additions:

*R. Velázquez Bosco, Cámaras sepulcrales descubiertas en término de Antequera. Rev. de Archivos, Bibliotecas y Museos 9, 1905, 413 (Romeral, Viera).

*M. Gómez-Moreno [Martínez], Arquitectura tartesia. La necrópolis de Antequera. Bol. de la Real Acad. de la Historia 47, 1905, 81-132 (Menga, Romeral, Viera).

P. Paris, Promenades archeologiques en Espagne: Antequera. Rev. Arch. 8, 1919, 239-271 (Menga, Romeral, Viera).

A. de Mortillet, Le dolmen d'Antequera. Assoc. Franç. pour l'Avancement des Sciences, 44' Session. Strasbourg 1920 (1921) 475 ss. (Menga).

*C. de Mergelina, La necropoli tartesia de Antequera. Soc. Esp. de Antrop. Etn. y Prehist. 1. Mein. 4, 1921/22, 37 ss. (Menga, Romeral, Viera).

3. Sources with explanations of the comparative classification of the sepulchres:

H. Obermaier, Die Dolmen Spaniens. Mitt. d. Anthr. Ges. Wien 50, 1920, 114 ss. — El dolmen de Matarrubilla (1919) 26 ss.

J. R. Melida, lberia arqueologica anteromana. Discurso de recepcion en la Real Academia de la Historia (1906) 31-40.

W. J. Hemp, The Passage Graves of Antequera and Maes Howe, Orkney. The Antiquaries Journal 14, 1934, 404 ss.

E. Thurlow Leeds, The Dolmens and Megalithic Tombs of Spain and Portugal. Archaeo logia 70, 1920, 201 ss.

J. Déchelette, Manuel I 149.

N. Aberg, Civilisation Eneolithique (1921) 20.

Cueva del Romeral.

Plates. 55. 58; Images: Plates. 98-102.

Location: from the entrance of the Cave of Menga a direct view is possible of the conspicuous rocky silhouette 
of La Peña de los Enamorados, the peaks of Sierra de Archidona rising right behind. In front of the former rises, about 2 kilometres from the Cave of Menga, in the middle of the plain, an artificial hill known by the name of Cerrillo Blanco due to its colour (Plate. 98,3) [Figure 1.B]. In this mound-like hill, the Viera brothers discovered the corbelled sepulchre of El Romeral Cave in August 1904. From Antequera this tomb can be reached by the Archidona road, taking a detour towards the north next to the sugar factory. After crossing the railway, we will immediately find the mound (Plate. 98,1) [Figure 2.A]. The mound is about 85 metre across, his height, which rises towards the north due to the sinking of the ground, is between 8 and 10 metres. Because of the erosion, the top is currently flattened. Recently, trenches have been opened that prove the artificial character of the mound, since features of black soil and organic remains mixed with sand, mud and pebbles were found. According to P. Paris, in the northern area of the mound there is a second construction, "some kind of gallery that descends steeply and does not lead to a chamber. From it, a small corridor turns to the left and to the right, near the entrance, [and] behind another corridor a larger room can be seen". To this date, it has not been possible to specify whether these are galleries made by looters or if they were really part of the original construction.

Form and construction: passage grave with two round, aligned and contiguous corbelled chambers, built with small masonry. The total length of the grave up to the point of intersection between the floor level and the edge of the burial mound is $44 \mathrm{~m}$. Of those, 10 $\mathrm{m}$. correspond to the chambers, 34 to the passage.

Orientation: S. $25^{\circ} \mathrm{W}$.

Outer antechamber: in the first texts about the tomb written by Velázquez Bosco and Gómez-Moreno [Martínez] in the year of its discovery, $25 \mathrm{~m}$ away from the entrance of the chamber there was still "a buried tall slab and other smaller stones that are not sufficient to define the form of the gate". The remains of this part of the construction are located on both plans on the left side, including a slab perpendicular to the longitudinal wall on the left side of the same height than the corridor, which is opposite, according to Gómez-Moreno [Martínez], to a gentle ridge of the wall that runs parallel at the same level. $1.5 \mathrm{~m}$ outside this place there is another narrowing of the corridor, much more pronounced on the left, thus delimiting a square space, whose wall on the left is totally occupied by a slab. These are probably the remains of an outer antechamber with the same form than that of El Vaquero cave and the Alcalá dolmens. Outside the location of this slab, the entrance is destroyed and buried.

Main antechamber: the main access space to the construction is a $23 \mathrm{~m}$ long passage extending, without inner divisions, from the outer gate to the portal into the corbelled chamber. It widens slightly towards the interior of the sepulchre, from $1.70 \mathrm{~m}$ to $1.80 \mathrm{~m}$. Measurements provided by different authors differ from one another due to the irregularity of the slabs on the wall.

Measurements of the height of the passage: GómezMoreno [Martínez] establishes the height in $2.0 \mathrm{~m}$. His section shows uniform heights. According to Mergelina's reports, who established the height in $1.85 \mathrm{~m}$, the height of the passage increases slightly towards the chamber. Based on these data, our measurements would be:

- $14.50 \mathrm{~m}$ of distance from the entrance of the chamber $=1.60 \mathrm{~m}$,

- $10.0 \mathrm{~m}$ of distance from the entrance of the chamber $=1.80 \mathrm{~m}$,

- $6.20 \mathrm{~m}$ of distance from the entrance of the chamber $=2.0 \mathrm{~m}$.

These measurements have been taken from the current floor. At the roofed part of the entrance the current floor level corresponds to the original one. The slight decrease of the height of the corridor must have occurred by the fall of the roof.

The walls are built with small masonry and protrude gently $-0.28 \mathrm{~m}: 10 \mathrm{~m}$ from the entrance to $0.37 \mathrm{~m}$ : $6 \mathrm{~m}$ from the entrance. This protrusion appears along the whole of the wall, so that the curve only deviates slightly from a straight line leaning forwards (Plate. 55 a.b) [Figure 3]. The building material of the walls is composed of grey marl-limestone slabs with inclusions of black dolomitic crystals. The materials are from a quarry different to that of the Cave of Menga and Viera materials. Partly, they are arranged in regular layers, [while] elsewhere thick slabs and small blocks have been introduced (g) [Figure 3]. In general, the construction is less careful than that of the chamber. The thickness of the slabs oscillates between 0.05 and 0.15 $\mathrm{m}$; the width varies amply; the length - in general between 0.40 and $0.50 \mathrm{~m}$ - could be set in some of the collapsed parts in up to $1.0 \mathrm{~m}$. The longest slabs, and occasionally also the thickest ones, can be found under the capstones. They are held together with layers of clay that reach deep into the wall, sometimes to the full thickness of the stone slabs. The clay layers do not stick out of the surface of the wall. The spaces in between are filled with fragments of slabs and gravel which, 
according to Mergelina, were only introduced once the wall had been finished. The wall seems much more regular than that of Matarrubilla's chamber and the lateral chamber of El Vaquero cave. In collapsed areas we could still detect, $1.0 \mathrm{~m}$ deep, slabs inside a thick layer of clay; next a mass of pebbles, clay and earth forms the transition into the artificial hill, into which stones were introduced to a depth of up to 2.0 in a badly destroyed part of the wall.

The capstones are large undressed slabs with a width of at least $1.50 \mathrm{~m}$ and a thickness of $0.40-0.50$ $\mathrm{m}$. On the collapsed parts of the wall it was possible to see a protruding element of about $1.0 \mathrm{~m}$, which corresponds to a length of the stone of almost $4.0 \mathrm{~m}$. The roofing is intact in the $15 \mathrm{~m}$ of length from the entrance of the chamber, with the exception of a fracture the size of a capstone about $10 \mathrm{~m}$ away. In total there are $10 \mathrm{in}$ situ capstones, of which four are broken due to the pressure of the soil. The capstones are placed partially diagonally with respect to the longitudinal axis, which cannot be observed in Mergelina's plan. The floor was paved with fitting slabs of varying sizes. The interstices were filled with small gravel.

The preservation of the entrance area is fairly poor: throughout its length only the lower half of the wall remains. Where the capstone is missing a shaft-like entrance has been made. In the roofed space, the outer wall layer is also fully disintegrated.

Main chamber: $4.80 \times 5.24 \mathrm{~m}$ in diameter, the height from the original floor is $3.80 \mathrm{~m}$, the upper opening of the dome is $2.20 \mathrm{~m}$ in diameter. Original height according to Gómez-Moreno [Martínez]: $4.0 \mathrm{~m}$.

The almost circular dome chamber conveys a sense of harmony due to its balanced measures. On the left side, the protrusion of the wall measures $1.42 \mathrm{~m}$. The curve of the dome is fairly straight, especially on its upper half; the biggest deviation from a straight line at $1.70 \mathrm{~m}$ above the floor is only of $0.24 \mathrm{~m}$. The beehivelike dome shown in Mergelina's section is not accurate. Like the corridor, the chamber is built with small masonry (Plate. 100,2) [Figure 2.E]. The construction technique is the same, although the slabs were more carefully selected. In the four lower rows, forming a regular line, are slabs of similar hardness, [while] the rows above are only partly recognisable. The thickness of the slabs varies slightly, the bigger ones measuring approximately $0.15 \mathrm{~m}$. The width rises to $0.21-0.40 \mathrm{~m}$. The length of the slabs in the layer of the front wall is generally not discernible; at a point, $0.65 \mathrm{~m}$ behind the front wall we discovered a second circular wall. Here, the slabs were also embedded in clay in layers matching the thickness of the slabs. In general, the walls seem fairly flat and smooth.

The upper circular end of the dome is partly made by the two upper rows of lightly thicker slabs, as it was also mentioned for the passage; individual blocks with a thickness between 0.20 and $0.40 \mathrm{~m}$ and up to $0.090 \mathrm{~m}$ in width, alternating here with normal masonry. Probably this is not by chance and it serves, like the pronounced "neck" present in other Andalusian dolmens, to provide stability, so that the slabs directly underneath the capstone recede on the blocks under them, instead of protruding. The dome is topped by a capstone of "brownish solid siliceous limestone", with measurements which, according to Gómez-Moreno [Martínez], are of 6.0 in diameter and 0.80 in thickness (Plate 102,4) [Figure 2.D]. For the dimensions of the chamber, the base line of the chamber exceeds the capstone by a short distance. Contrary to Pastora, Matarrubilla and even Vaquero, here the capstone is centred on the aperture of the corbelling, an incomparably more artistic construction.

The floor of the main chamber is paved like the main entrance. Currently, apart from various cavities like niches on the right, a large portion of the wall is damaged.

Secondary chamber (Plate 100,1) [Figure 2.G]. A second, smaller corbelled space is connected to the main chamber through a corridor built with an exceptional construction system described later on. The access and secondary chamber are not on the projection of the longitudinal axis of the rest of the construction, but instead are some $10^{\circ}$ off $-0.50 \mathrm{~m}$ on the back wall of the main chamber - towards the south. The secondary chamber, built with the same technique than the main chamber has 2.34 metres in diameter and $2.40 \mathrm{~m}$ in height. The aperture of the dome is $0.90 \mathrm{~m}$; the protrusion is therefore approximately $0.70 \mathrm{~m}$. The top part of the corbelling protrudes, as it is visible in a damaged part, 1.20 beyond the edge of the dome; it should therefore be a little bigger than specified in Mergelina's section. On the lower side of the capstone there are some incised lines, of which a triangle with a central line, crossed by another transversal line, seems to be artificial (c) [Figure 3]; this impression is confirmed by comparison with the similarly-designed grooves in the remaining slabs of Alcalá 1 (Plate. 77, Grave 1 b. c. d).

The access floor to the secondary chamber rises $0.70 \mathrm{~m}$ above that of the main chamber and according to Mergelina remains at that level inside the secondary chamber; on the other hand, Gómez-Moreno [Martínez] and Velázquez Bosco claim that the floor 
descends again after the entrance, so that the lower face of the slab described next is at the same height as the access floor. These parts of the grave were filled with debris and we did not examine them. The entire back half of the chamber is occupied by a large $0.30 \mathrm{~m}$ thick limestone slab that rises $0.20 \mathrm{~m}$ above the chamber floor and is embedded in the wall. Its frontal side is cut or broken through the middle. On the dressed upper side some marks are visible that may have resulted from the decomposition of organic substances. The chamber is considerably damaged in some parts, [and] on the right side there are two funnel-like holes.

Intermediate passages and gates: both between the access corridor and the main chamber and between the latter and the secondary chamber there are ingeniously erected corridors, in principle built in the same way.

Gate 1 and corridor [intermediate] towards the main chamber (i. k.) (Plate. 99,1) [Figure 2.B]. Two jambs of almost square transversal section $1.60 \mathrm{~m}$ in height, embedded in the walls of the corridor, protrude some 0.30 or $0.45 \mathrm{~m}$. Inside these jambs, withdrawn $0.50 \mathrm{~m}$ towards the chamber, two slabs $0.25 \mathrm{~m}$ in thickness of the same height define the aperture of the gate, which has a width of 0.69 on the corridor side and 0.78 on the chamber side. The slabs lean slightly inwards, so that the space of the gate narrows slightly towards the upper part $-0.10 m-$ in a trapezoidal shape. On the side of the chamber, these two blocks are chamfered on their upper half. This can be explained by the wish not to interrupt the curvature of the wall at the straight vertical edges of the gate's frame in its total height of $1.60 \mathrm{~m}$. As a result of this chamfer it was possible that, already some 0.80 above the chamber floor, and by means of the small masonry placed on the beveled edges, the curvature of the gate started in harmony with that of the wall, which also included the corresponding protruding upper lintel (Plate. 101,1) [Figure 2.C]. As anticipated, this effort is revealed much more clearly at the inner gate of the secondary chamber; here, just above the chamber floor, the chamfer of the slabs of the gate's pillars starts, and therefore the dome of small masonry starts. In addition, the upper lintel not only protruded towards the curve of the dome, but was also exactly adapted to the chamfered edge (Plate. 100,1) [Figure 2.C].

The [intermediate] corridor is roofed with a slab that is visible both in the chamber and in the corridor as lintel of the gate. In the chamber, it protrudes approximately $1.0 \mathrm{~m}$ on both sides beyond the gap of the gate; between it and the jambs, a layer of masonry was laid, not in a poor fashion, as P. Paris assumes, but in a well-planned one, as the same technique appears at
Cave of Viera. Masonry can also be found between the lintel and capstone of the corridor, placed about $20 \mathrm{~cm}$ higher. The thicker slabs protruding on the sides form a supporting device here.

Corridor and gate to the secondary chamber (d.e.) (Plate 99, 2) [Figure 2.F]. Probably, in order to interfere as little as possible with the unified impression of the corbelled dome, avoiding the interruption of the gate's vertical jambs, a simple aperture in the wall was made at the entrance of the corridor from the main chamber into the secondary chamber, narrowing upwards in a trapezoidal shape, according to the diminishing of the dome- This aperture, today $1.90 \mathrm{~m}$ high, seems to have emerged further below, although when evaluating its shape it is convenient to consider that the threshold to the secondary chamber is also slightly rounded at El Vaquero Cave.

The first section of the corridor [to the second chamber], $1.20 \mathrm{~m}$ in depth, is built with small masonry and widens inwards from 0.70 to 1.0 and is paved. The true space of the gate follows afterwards, with jambs that, like in the first corridor, are built with the lateral edges of two slabs, which delimit the walls of the rear part of the corridor. These slabs protrude on both sides of the corridor in 0.12 or $0.18 \mathrm{~m}$ and provide the gate a span of $0.68 \mathrm{~m}$. Towards the secondary chamber the section of this space also broadens again like a trapeze up to $0.76 \mathrm{~m}$.

The roof of this corridor [into the second chamber] is much more important than that of the main corridor. This is partly due to the knowledge that this part of the architecture between both domes demanded an extraordinarily robust stability, much more than that of the first corridor. The three slabs used to roof it are at different heights, the interstices filled with small masonry. Thus, a distribution of the weights is obtained. At the bottom, [serving] as lintel of the gate, the lower capstone is found, this section being, therefore, lower. In the chamber, this capstone recedes slightly in the wall and it is possible that originally it was completely covered by a coating. The weight of the dome without a visible horizontal beam is achieved thanks to this slab leaning slightly and vanishing into the left wall, whereas a slightly thinner slab is superimposed obliquely in an obtuse angle with regard to the former from the left. A similar arrangement can be found at El Vaquero Cave.

El Romeral Cave is justly regarded as the most beautiful example of prehistoric corbelled architecture in Iberia. Among the Andalusian and southern Portuguese graves of similar construction none can compete with it, neither in the magnificence of the whole complex, 
nor in the pondered and detailed execution of the architectural details. This care in the construction is probably the reason why this unique monument has been preserved almost complete to our day.

Beyond the knowledge of the foundations of architecture, a unified artistic will is perceived everywhere. The interest in the dome and the curved line, the omission of the straight line at all costs possible, are not only found in the arrangements of the gates to the corbelled chambers dealt with here, but also in the trapezoidal broadening and narrowing of the corridors. The ideas that sprung to mind when we took into consideration the details of the construction of the grave are explained in great detail and discernment in Mergelina's report.

Report of the excavation and finds: when it was discovered, the sepulchre had already been looted and backfilled with loose earth to a great height. In the chamber, the infill was $0.80 \mathrm{~m}$ high: an upper layer of soil without human remains was found; underneath a darker and more compact layer with layers of black ash, probably mixed with organic remains, in the middle a great amount of smashed human remains, some fragments of pottery and two fragments of marine shell of the Lithodomus and Mactra species. As far as it is possible to judge by the fragments, the bones correspond to small individuals. No skulls, but two mandibles and a fragment of a third. In the secondary chamber, under the floor slab, a horn, like that of a young bull, was found. In the access corridor some bones of small animals were found together with a lot of pottery including a Roman hydria and fragments of bricks as well as that of the time of the construction of the graves. No finds in the intermediate corridor.

Among the pottery, the following fragments are worth noting (Plate 58, Sepulchre 1) [Figure 4.A]:

1) From the corridor: hemispherical vessel $0.10 \mathrm{~m}$ in height and $0.18 \mathrm{~m}$ in diameter, and between 1 and $3 \mathrm{~cm}$ in thickness, of black clay with some reddish shades and quartz inclusions; It was found in the corridor near the entrance (1) [Figure 4.A.1]. Fragment of vessel with slight curvature, higher wall, and $7 \mathrm{~cm}$ high, $11 \mathrm{~cm}$ of thickness, yellowish, back fracture (2) [Figure 4.A.2]. Fragment of another vessel with straight conical wall. Pieces of the rim of a large vessel $7 \mathrm{~mm}$ in thickness, black, polished, with slightly off-set groove below the rim (3) [Figura 4.A.3]. Fragments of rim, of well fired, black, polished, $7 \mathrm{~mm}$ in thickness with a curved extruding rim (5) [Figure 4.A.5]. Two pottery fragments, one triangular and nother elliptical, with marks of rubbing; reddish yellowish shade.
2) From the chamber: all pottery from the chamber is undecorated, well fired, completely blackened, and with fine compact fabric, burnished exterior. Some fragments are $7 \mathrm{~mm}$ thick. Recognisable: fragments of the rim of a large hemispherical bowl with recoiled rim (6) [Figure 4.A.6]. Fragments of rim of a vessel with narrow neck and extruding rim.

Description of the pottery according to Mergelina a.a. 0.84 .85 .

The objects in the collection of the Viera brothers, Antequera $^{1}$ ).

Cave of Menga.

Plates 56. 58; Images: Plates 97. 98. 104. 105.

Location: The grave is located outside the city of Antequera, on the Archidona road. $1 \mathrm{~km}$ from the last houses, a footpath branches out from this road and descends towards the north and the valley, where the grave is located approximately $20 \mathrm{~m}$ away. The great capstone of the entrance can be seen from the footpath (Plate 98,4) [Figure 5.A]. The ground descends rather abruptly about $10 \mathrm{~m}$ away from the entrance towards the plain (Plate 97,1) [Figure 1.C].

Exploration: Nothing is known about how long the sepulchre has been open. The first evidence about it is provided by Mergelina through a writing by R. M. Silva (1675). In the year of 1842, R. Mitjana found the grave already completely looted. For some time, it had been used for practical purposes. The fact it was known by the people since long before is proven by the legends connected to it (P. Paris a. a. O. 244). The earliest scientific description came from R. Mitjana, an architect from Malaga; information concerning ulterior investigations is provided in page 173. To this date, the origin of the Menga name (Mengal?) is unclear. Of the various conjectures, only one seems to be well grounded: it connects it with an old gypsy song about the Baena menhir, both is in connections with legends about a giant ${ }^{2}$.

Preservation: The architecture is so good that it appears completely preserved. Maybe some uprights and capstones of the outer part of the entrance are missing. Behind the backstone, the mound is partly destroyed, with the backstone exposed as well as is the outer capstone. The upper right corner of the backstone has an aperture of approximately one square metre, probably made by looters who may have easily entered here through the mound.

Orientation: E. $30^{\circ} \mathrm{N}$. 
Form and construction: Passage grave with long oval chamber. Total length $25 \mathrm{~m}$, total width $5.50 \mathrm{~m}$, current height: from 2.70 to $3,20 \mathrm{~m}$.

Chamber: The chamber is more clearly distinguished from the corridor than in other sepulchres with long passage and galleries of the south-west. The grave can be connected with other graves of the south-east, specifically the group of trapezoidal chambers with completely oblique walls. Length of the chamber:16.25 $\mathrm{m}$, built with 7 uprights [each wall], a backstone and five capstones.

The $3.5 \mathrm{~m}$-wide backstone is placed between the lateral walls (in the style of Portuguese constructions). The contiguous lateral uprights lean gently outwards; the widening of the chamber starts here. As for the walls of the chamber, the left side displays a regular curve; the position of the uprights on the right side is less curved and more irregular. The chamber is widest $-5.40 \mathrm{~m}$ - approximately $5.50 \mathrm{~m}$ away from the backstone to the last pillar. From here the space gradually narrows down to the 2.25 metres of the entrance.

Passage: the passage starts with 3.05 in breadth next to the chamber; the lateral sides of the last uprights of the chamber, extremely thick, are free in their half to the side of the passage and form the jambs of the gate. The separation between chamber and passage is more clearly seen in the image of Plate 104,2 [Figure 5.D], as seen through the naked eye on the plan. This arrangement for the entrance is like some the Atlantic passage graves of polygonal type; the inclusion of the edges of the stones in the architectural configuration demands the use of thick blocks, which in the south-east are rare as uprights. However, beyond this purely technical reason, there is the absence of a transversal entrance slab cutting through the vertical wall, another proof of the relationship with Portuguese polygonal chambers.

Five uprights of the passage are preserve on each side. The overall length of this part of the construction is nowadays $8.70 \mathrm{~m}$, its width is reduced to $2.0 \mathrm{~m}$ toward the entrance, outside the fourth orthostat. With the fifth, today last upright, a new widening of the corridor occurs again. It is unclear whether the oblique arrangement of the outer uprights comes from the original construction. Generally, it is assumed that uprights were displaced from their position at a later time. However, there are multiple parallels of the widening of the passage as an atrium in this type on graves. A study of the mound could shed some light on this issue. According to the design of this work, it is possible to assume a longer primitive length of the construction in 1 or 2 uprights, even with that extension, in approximately $4: 3$.
The passage is, therefore, remarkably short if compared with the graves of Romeral and Viera and other large sepulchres of Andalusia and southern Portugal. With this plan we remain entirely in the domain of southeastern architecture.

We will come back to a possible subdivision of the passage in the construction of the tomb.

Mergelina draws a second line in the plan, which matches the lower point of the uprights in general and only at the back of the chamber is located at approximately $1.0 \mathrm{~m}$. According to his description, this line represents a 0.20 -wide groove located on the capstones, which he sees as a sketch of the construction. The execution would have been so thought out that in the preparation of the roof - which probably demanded the prior joining of the stones outside the grave - the plan of the chamber had been marked out on the lower side of the capstones. Originally, the chamber would have been planned to be shorter. This groove can be observed in the some of the capstones (Plate 104, 1 above right) [Figure 5.E]. On the lateral walls it is not entirely clear how the groove along the curve drawn by Mergelina can be seen as, given that the uprights bend forward, the base of the plan is considerably further back to the intersection point of the capstones and the uprights. In addition, it seems remarkable that such sketch, which would provide evidence of a well-planned architecture should anticipate the accidental irregularities in the direction of the wall. It seems necessary to test these observations. In our opinion, it would also be conceivable that a draft of the shape of the chamber on the capstones was intended to prevent an excessive lateral displacement of the capstones when they were laid in their position.

Construction: the burial construction is embedded in a natural hill. On its northern side it is cut so near to its top that the capstone at the back of the chamber is at the same level as that (Plate 56) [Figure 6]. The bedrock of the hill is made of limestone, which is easy to work. The depth of the excavation of the rock is uncertain. According to Mergelina, the ditch in the rock could reach up to the upper side of the uprights, which is feasible considering analogous cases at Gandul.

In the earliest literature it is repeatedly claimed that the grave was located in an artificial hill. This assumption is probably based on an investigation by P. Paris, who discovered a 0.60 -wide wall behind the uprights. In fact, both observations do no exclude each other. The construction probably resembles the Gandul megalithic galleries, in which the uprights do not rest directly against the side of the foundation ditches, but 
stand approximately $0.50 \mathrm{~m}$ away from it, as the space in between is filled with stones and packs of clay. The remains of the mound, preserved over the chamber to $3.0 \mathrm{~m}$, flattened at the top, are also composed of clay and layers of stones.

Except for the backstone, which is vertical, uprights lean gently, especially on the right wall, with an average of $0.35 \mathrm{~m}$. Precise investigations are required about the length of the uprights, their standing on the bedrock $^{3}$ and the original floor of the chamber. Mitjana points out that the uprights are inserted between 1.0 and $1.5 \mathrm{~m}$ into the floor of the chamber. Mergelina's section suggests that the floor marked by him - at the backstone, and therefore $3.20 \mathrm{~m}$ of height of the chamberis the original, since the wedging of the pillars and the backstone is set here. In 1905 Gómez-Moreno [Martínez] assumes an infill of earth in the grave of approximately $0.67-1.30 \mathrm{~m}$. The comparison between the plans of Gómez Moreno [Martínez] and Mergelina, as well as the photographs of 1905 and 1934, prove that the floor of the chamber is today at the same level it was back then. The 1904 excavation that led to the discovery of a stone hand axe at a depth of $0.50 \mathrm{~m}$ into the floor, suggests that the original floor was in fact lower than in Mergelina's section.

Therefore, the following questions still remain unsolved. Is the wedging of the pillars and the uprights really at 3.20 below the capstones? Where is the natural rocky bedrock?

Only establishing these facts can provide information about the height of the chamber, as well as the rise or decrease of the chamber floor. The issue of the deepening of the floor in the section of the corridor closest to the chamber, according to Mergelina 0.45 into the volcanic tuff, also remains to be examined. The height of the grave diminishes around $1.20 \mathrm{~m}$ towards the outer end of the roofed space by the steady and gentle sloping down of the roof.

The chamber is roofed by four capstones, the antechamber with a further capstone which is equivalent in size and thickness to those of the chamber, or even bigger. There is no evidence here of the usual change from large-sized to smaller capstones which in most extensions of passages are at the same time more coarsely worked. Therefore, this section of the room can be best described as antechamber. Of the four uprights outside the roofed space, Mergelina draws in the inside of the right side at the same height than the wall of the antechamber. However, it only has 1.50 in height and does not seem to be broken. The three remaining uprights of the wall are only 0.80 in height. They are all less carefully worked, and perhaps they represent the limit of an open antechamber, which is also suggested by the design of the plan.

Material, dressing: The construction material is hard limestone (Tertiary Jurassic) quarried from Cerro de la Cruz (Calvario), $1 \mathrm{~km}$ away from the grave. All stones are dressed with stone tools on their inner face, as well as the sides and upper edges. The combination of the individual uprights and capstones is, just like the fitting between the roof and the wall, very precise; the comparison with other Andalusian passage graves and galleries suggests a much more meticulous work. Due to the regularly rectangular shape of the stones there rarely are empty angles on the upper and lower corners; therefore, it is almost unnecessary to add any stone infill anywhere in the walls formed by the uprights. In the small interstices between the wall and the roof wedges of stone were introduced. The thickness of the uprights is approximately $1.0 \mathrm{~m}$, that of the capstones is up to $2.0 \mathrm{~m}$. Mortillet provides a table with all the measurements.

For such finely dressed walls there is hardly any parallel throughout the entire Atlantic region. If we duly discard the round graves, lined with fine slabs, belonging to another architectural group, there is only some old design of trapezoidal chambers in the west coast of Portugal ${ }^{4}$ which are still in need of a review. In the south-east, on the contrary, some examples are available, including especially Grave 1 of Alicún (Plate 126,4). The fitting of the stones by means of a fold is only achieved in the upper left stone of the entrance to the chamber.

Out of the four capstones of the chamber, the one that covers the rear of the chamber is the largest. It does not fully pass over the backstone, which must only be considered a supporting device, like the pillars; the support for that capstone comes from the lateral uprights. There is no precise evidence showing to what distance the capstones go over the lateral orthostats. The maximum size of the capstone accepted so far is $8.0 \times 6.30$ $\mathrm{m}$ in length, which still falls short, as that would mean that at the widest point of the chamber the capstone would hardly go over the walls. Whether the walls support any weight or if, like at Gandul, the infill does it, still remains to be studied.

Pillars: the roof of the chamber is supported by three central pillars that divide the space in two naves along its longitudinal axis. These pillars are located exactly underneath the joints of the capstones. They are coarsely dressed, their transversal section irregularly rectangular or square. The largest of them has a surface 
at the base of $1.30 \times 1.10 \mathrm{~m}$. Nowadays the impression of a widening upward of pillars 1 and 2 endures, which is wrong, as the concavity in their lower part must with certainty be attributed to a later period. Pillar 3 narrows down on its upper part, although here an excision of the outer upper part must be also contemplated. It may be assumed that pillars were intended with a fairly uniform base. Thus, according to Mergelina, they are embedded in the rocky ground in conical sockets. As it was discussed before, not all remaining questions about the depths of the foundations and their wedging have been answered. The non-perfectly vertical position of the pillars reinforces the impression of coarseness suggested by the irregular shapes. Today, pillars 1 and 3 deviate between 0.18 and 0.20 of the vertical mark. As it has been mentioned in almost all descriptions of the grave, the pillars are not in contact with the capstones almost anywhere. The farthest pillar (3) appears slightly surrounded on its upper part and adapts to the sides of the capstone, which are worked on the obverse of the stone. In the central pillar (2), the upper part is curved irregularly; above it lays the capstone of the inner side, whereas on the outer side a fairly broad space between the roof and the pillar is filled with small stones and coatings (Plate 105, 2) [Figure 5.F]. The front pillar (1) is better adapted to the form of the capstone, but without touching it. The infills are also visible here.

This peculiarity in the arrangement of the pillars has led to several hypotheses. Obermaier, P. Paris and Hemp think it possible that the pillars were erected at a later date. The latter considers the possibility that the breaking of capstone 3 led to the construction of a support for the roof. According to Hemp, the intermediate layer of infill of stones is conceived as a support for the pillar, like some kind of abacus. Mergelina, on the other hand, thinks that the pillars were put in place before the capstones and an error in the calculations led to the undesired difference.

Precise investigations of the shape and depth of the pillar sockets must provide the basis for a question: namely, whether a later erection would have been at all possible. The treatment of the edges of the capstones would support such theory. So, for the time being, before the definitive study of the construction is achieved, the question can only be answered from the cultural point of view. In this case, our opinion is that the erection of the pillars took place at any rate within the timespan of the construction of the tomb. The wealth of material available for comparison of the construction of the pillars leads us to this assumption. In addition, the use of coating in the south-east fits entirely in the apogee of this cultural period. Hence, we want to express our assumption that the pillars, that today appear coarser than the uprights, were originally coated with plaster, for which there are examples at Los Millares and Belmonte. Regarding the capstone, we think it is possible that precisely an undue tension caused by the irregular layout of the pillars led to the breakage by collapse of the inner layers.

The technical execution of the construction has always caused amazement and wonder. The space, created with a limited number of stones, has a volume of 200 cubic metres; the chamber alone spans over 67 square metres. Calculations for the stone slabs return, for the largest capstone, which has a thickness of $2.0 \mathrm{~m}$ and a volume of at least 60 cubic metres, a weight of at least 170 tonnes. P. Paris asks "what architect in our day would dare, while working exclusively with slabs of stone, to put such mass on such a span?" The issue of the means available in that period for the erection of the construction has thus been frequently debated by architects in particular, and that is why we refer to the detailed essay Mergelina devoted to this issue.

The Menga Cave is one of the few tombs (and among them, the most impressive) in which the concept of the construction of a sheer megalithic building - the imposing wall, the heavy roof - forms an artistic space and increases the artistic effect. Despite the enormous blocks, the impression is one of freedom and harmony; the pillars reduce the space to a lesser extent than the vertical weight, carrying the extreme burden of the roof to a balanced measure. The gentle convexity of the wall broadens the chamber beyond what could be expected from the plan, which certainly causes the impression of a modelled room and not a long passage. The walls closing on themselves vanish into the darkness of the back of the chamber, which appears more rounded as the pillars hide the backstone. The balance of lights on the walls and the floor caused by the position of the pillars livens the chamber picturesquely.

The solemn impression of this two-nave room matches our idea of sacred constructions. This convincing comparison with purposely designed architecture begs the question of whether beyond the sheer technique, the knowledge of the laws of artistic construction is present here, as reflected in the forms and pillars described above. Certainly the effect is mainly based on the appearance of original principles of architectural design in their most primitive form, which steer us back towards a period in the history of architecture when what construction demanded as functional, was by the magnitude of the objective, producing an 
immediate artistic effect, which only in later periods would be formed due to cognition. However, this is only one component of the construction's effect. The second is unmistakably found on the broadening of the room through the direction of the wall, that is to say, a modification borrowed from circular construction. The way the narrow limits of this modification are implemented in the pure megalithic construction proceeds from the entire history of polygonal passage graves. The largest graves with purely octagonal plan in the Portuguese mainland never succeeded in creating impressive interiors. The expansion of the space beyond the dimensions achieved there, in approximately $6 \mathrm{~m}$ in diameter, must always be attributed to long spatial forms. The rounding of the wall in the Cave of Menga is just faint, because the roofing does not allow to venture the overcoming of larger breadths.

The position of the Menga Cave is, according to its architectural form, determined by that and its importance was established already by Gómez-Moreno [Martínez]. To what extent graves of similar design that have yielded finds, details about the construction and comparison with the tombs of the south-east can help us advance in the research of their chronology, can only by shown by the summary.

Excavations (Plate 58, Sepulchre 2) [Figure 4.B]: The excavation by Mitjana in 1842 did not yield any results. According to Trinidad de Rojas (1874) “coarse tools of dark hard stone" were found in the grave. In a small excavation in 1904, Don Mariano de Mazas found a blackish serpentine, broad neck, oval transversal section, dull edge, totally polished axe in the angle formed by the backstone with the lateral wall on the right, at a depth of $0.50 \mathrm{~m}$ (2) [Figura 4.B.2]. Mergelina found a second axe in the first stone from the outside on the left side, very close to the wall; flat adze with broad neck, rectangular transversal section, blackish rock, curved upper end and well-polished edge (1) [Figure 4.B.1]. In addition, Mergelina found a coarse tool with the shape of a disc: some kind of axe, on one end suited to he held, on the other a dull edge, which he supposes was a tool to dress the stones of the tomb. The stone tools mentioned by Rojas were probably of the same type.

Grave goods according to Obermaier and Mergelina.

Engravings: on the third upright of the passage on the left, $0.14-0.20 \mathrm{~m}$ below the capstone there is a series of engraved symbols (a) [Figure 4.B.a] (Plate 140,2) [Figure 5.C]. They include four crosses with a length of $0.18-0.47 \mathrm{~m}$, three of which have a semicircular base, which in two of them protrudes slightly from the rocky surface, the third finished by two deep grooves surrounding it. At $0.18 \mathrm{~m}$ below the second cross from the left there is a five-point star $0.18 \mathrm{~cm}$ in diameter, also engraved on the surface. This motif is more clear and less weathered than the crosses, which can be explained because humidity is more intense near the joint. The dating of the engravings to the period of the construction is likely according to the engravings of the Soto dolmen. In the upper part of the last stone of the right-hand side of the chamber we note traces of another engraving (b) [Figure 4.B.b]. It is $14 \mathrm{~cm}$ in length and probably belongs to the same period.

Engravings according to the drawings by the Leisners.

\section{Cave of Viera}

Plate 57. 58; Images: Plate 106.

Location: the top of the hill on whose north-eastern slope the Menga Cave is built, forms, to the south-west, towards the town, an undulating plateau that descends gently. The Cave of Viera opens $88 \mathrm{~m}$ to the southsoutheast of the entrance to Menga.

Form: passage grave; overall length $21.40 \mathrm{~m}$.

Orientation: E. $10^{\circ} \mathrm{S}$.

Exploration: the grave was discovered in 1903 by Don José Viera Fuentes, an Antequera city council gardener from whom it takes its name. The discovery and earliest excavations were undertaken by Viera and his brother. The grave had already been looted at that time. The first scientific reports were written by Velázquez Bosco and Gómez-Moreno [Martínez].

Conservation: the chamber remains almost intact; in 1933 some uprights and capstones of the passage had collapsed; currently work is being undertaken to reconstruct the passage and stabilise the mound of the grave. The outer section of the passage is partly destroyed. The looters made a hole in the backstone and the rocky wall behind it and then hollowed up a corridor behind the right hand side of the chamber and the wall of the passage.

The construction material - yellowish limestone with quartz inclusions - is the same as in the Cave of Menga and comes also from the Cerro de la Cruz quarry.

The dressing and fitting of the stones shows, especially in the chamber, a detail and quality unparalleled in Iberian megalithic constructions. For that reason, Velázquez Bosco assumes they were worked with metal tools and also Gómez Moreno [Martínez] favoured that view. Later, however, a careful examination established that the round and conical marks on the stones must 
have been made with stone chisels or axes. Regarding the construction process: in an area exposed by looters it is possible to see, at the edge of the dig, the marks of levers that would have been used to place the uprights in position.

Form and construction: as in the Menga Cave, the space of the grave is undercut in the bedrock - calcareous tuff - of the hill. The edge of the ditch in the rock is approximately $0.70 \mathrm{~m}$ deeper than the upper edge of the chamber's capstone; its wall is $0.60 \mathrm{~m}$ behind the uprights. The space in between is filled with a wall built with alternating stones and clay. Behind the collapsed uprights of the passage we saw fragments of individual slabs embedded in clay.

Chamber. Square, $1.75 \mathrm{~m}$ in length and breadth. The chamber creates a slightly over-sized cube with $2.08 \mathrm{~m}$ in height. It is built with four uprights, the backstone and the frontal stone are provided with a chiselled hole, they are the main stones of the chamber and are taller than the uprights on the sides, exceeding them even in breadth and thickness. Vertical grooves were made on their inner faces of the capstones, to which the lateral stones are joined perfectly.

The uprights of the chamber are placed vertically; given the limited the space, the strength of the fitting of the walls grants sufficient stability, even without them leaning inwards. The chamber is covered with a large capstone $0.65 \mathrm{~m}$ thick, with dimensions that in earlier publications are indicated as $5.0 \times$ 5.0. In Mergelina's plan, the capstone it a little shorter $(3.60 \mathrm{~m})$ in its projection backwards.

The floor of the chamber is nowadays formed by the weathered natural rock; according to Velázquez Bosco's plan it is lower than that of the passage; and in it a round pit can be found made by looters, who at the same time, perhaps also tore off the pavement.

Passage: The access to the burial chamber includes two sections clearly delimited both in plan and the style of construction.

Main antechamber: This is the closest part to the chamber, with $1.30-1.35 \mathrm{~m}$ of width and $15.60 \mathrm{~m}$ of length. At this distance from the entrance to the chamber, a second perforated portal is found. The part of the grave that because of this is characterised as a burial space, was originally limited to 12-13 uprights on each wall, of which 4 are missing today. The walls run in parallel; the uprights, of varying width, are fairly close together and lean gently inwards. Today, the height of the main antechamber is 2.10 near the chamber and 1.90 at the stone of the outer portal, as the roof slopes down. Velázquez Bosco sets the height of the passage at $2.40 \mathrm{~m}$ which, in light of the position of the perforations in the portals, is unlikely. The capstones do not touch upon the uprights directly as between them there is a thin layer of slate slabs partly held together with mud. This particular element is also found in the chamber. This intermediate layer is shown clearly in Plate 106,1 [Figure 7.A]; in addition, the image suggests that the capstone of the chamber is on a slightly lower position than the capstones of the passage and slightly more forward than shown in Mergelina's section. The drawing by Velázquez Bosco exaggerates a little this part of the construction, but is more accurate. There is no reliable information concerning the real length of the uprights and their setting into the ground. The floor runs horizontally; the base points of the holes in the portals are at the same level. Originally it was paved with thin slabs. Between the pavement and the rock there was a layer of earth. According to Santos Rocha, who uses a report by F. Francesco y Lozano, there were small slabs partly set vertically and were connected by thin slabs of blackish stone. But the report is not clear on this point.

Four capstones of the passage, the nearest to the chamber, are preserved. They are more irregular in shape than those of Menga, but they are nevertheless well joined, with a maximum thickness of $0.80 \mathrm{~m}$. Remains of another two broken capstones can be seen on the right side of the wall. The outer-most of the them, $0.45 \mathrm{~m}$ thick, rests directly on the portal-slab of the corridor. The capstones protrude from the lateral walls up to $1.70 \mathrm{~m}$, and therefore in all cases they rest on the natural bedrock. Between the upper edge of the ditch cut in the rock and the capstones there is a wall with layers of clay and slabs (c) [Figura 8].

Portal slab 1. Gate to the chamber (b) [Figure 8] (Plate 106,1) [Figure 7.A]. On the slab closing the chamber, $0.60 \mathrm{~m}$ in thickness, a rectangular portal was carved out. Height: on the left $0.87 \mathrm{~cm}$, on the right $0.85 \mathrm{c}$. Width: below $0.72 \mathrm{~m}$, above $0.75 \mathrm{~m}$. The inner lateral surfaces were left flat, not curved. The threshold is a straight surface leaning slightly towards the chamber. The inner upper edge is rounded downwards; somewhat irregular, so that it creates a gentle crest, a little closer to the lateral of the chamber. This suggests that the chiselling was carried out from both sides. The upper edge of the portal is $0.88 \mathrm{~m}$ below the capstone, the lower edge $0.25 \mathrm{~m}$ above today's floor, probably $0.30-0.35 \mathrm{~m}$ above the original floor. The distance between the gap of the portal and the uprights is $0.25 \mathrm{~m}$ on the left and $0.35 \mathrm{~m}$ on the right; the total visible breadth of the portal slab on the outer face is therefore $1.35 \mathrm{~m}$ (Plate 106,1) [Figure 7.A]. 
Portal slab 2. Gate to the passage (a) [Figure 8] (Plate106, 2) [Figure 7.B]: on this portal slab a rectangular gap $0.98 \mathrm{~m}$ in height and $0.76 \mathrm{~m}$ in breadth was carved. Above the gap the slab is currently broken for the entire width of the gap. In our visit on February 16 1933 we noticed slightly protruding edges on the upper left and right corners of the portal gap, which remained there when the stone broke off. This prompted us to uncover the floor, leading to the discovery of the fully preserved lower edge of a carved portal gap. This had never been mentioned in the previous literature; Hemp publishes the portal gap, whose lower edge we uncovered, in a paper from October 1934. Seen from the outside, the inner sides of the portal gap deviate $5 \mathrm{~cm}$ towards the left off the vertical; they are, like the threshold, smoothly carved, the corners slightly rounded. The portal slab is $0.50-0.60 \mathrm{~m}$ in thickness and presents a visible breadth of $1.20 \mathrm{~m}$. Considering that on the left of the gap it presents a width of at least $0.65 \mathrm{~m}$, it is possible to assume a total breadth of $2.0 \mathrm{~m}$. The height from the upper edge of the gap to the capstone is 0.53 , shorter than in the chamber portal, which can be explained, as already mentioned, by the fact that the roof of the passage slopes down gently outwards. According to the portal of the chamber, the height of the threshold can be assumed to be $0.30-0.35 \mathrm{~m}$. The height of the portal stone, with $1.80-1.85 \mathrm{~m}$ matches so far the height of the passage measured at this point. As is common at Los Millares, the outer gap of the portal is larger than the inner one.

Outer passage section: outside the portal of the passage there are three uprights, two on the right and one on the left. The fact that the one on the left has the same height as those inwards of the passage portal, proves that the outer passage section at that point is as high as the main antechamber. The uprights on the right side are slightly shorter. All these slabs are coarser than those inside the grave. The remaining uprights have a length of 2.70; outside this the tomb is still visible from two metres away, then followed by the gently sloping natural ground. The width at the portal slab is $1.20 \mathrm{~m}$, therefore corresponds with the outer part of the main antechamber.

Mound: The mound, built with clay and stones, is $35 \mathrm{~m}$ across and is preserved today to a height of almost 4 metres above the chamber.

Architecturally, the Cave of Viera lies at the exact opposite end of El Romeral Cave; where the latter shows the idea of the dome and the curve, the former finds the base of the construction in the straight angle. Among the megalithic tombs of Iberia, none represents consistently that principle of construction in every detail - plan, vertical arrangement, shape of the stones, gaps on the portals.
Burial, grave goods. The thorough looting of the grave did not allow any observation to be made about the placement of the internments. Finds are also scarce due to looting. Specific positions are not known. The chamber was filled with black earth, where some small bones were found.

The following objects come from the antechamber (Plate 58, Sepulchre 3) [Figure 4.C]:

Polished stone: Small sharp axe with oval transversal section, damaged on the edge. Grey granulate stone (1) [Figure 4.C.1]. Flat axe with wide neck with trapezoidal transversal section, bent upper arc, blackish stone (2) [Figure 4.C.2].

Flint: 14 fragments of thin blades, $4.6-8.1 \mathrm{~cm}$ in length (6 - 12) [Figure 4.C.6-12]. The following items stand out: $\mathrm{n}^{\circ}$ 8.10: thin fragments of blades with trapezoidal transversal section and circular retouch on the edge. $\mathrm{N}^{\circ}$ 11: upper part of a broader blade with retouch on the edge in both sides. $\mathrm{N}^{\mathrm{o}} 12$ : narrow blade, very thin and slender with fine serrated retouching on both edges. $\mathrm{N}^{\circ}$ 9: fragment of blade with pointy burin shape. Another 7 smaller fragments of similar blades, among them two pointy ones like $\mathrm{n}^{\circ} 9$.

Bones: 1 fragment of bone (3) [Figure 4.C.3]. 1 Horn point (4) [Figure 4.C.4].

Limestone: stone vessel. White stone in the shape of a disc, lowered on both sides (14) [Figure 4.C.14]. Next to this stone the copper punch was found. 1 vessel with foot, thick wall, abruptly withdrawn below the rim, gently lowered (13) [Figure 4.C.13]. Two orangesized limestone balls.

Copper: 1 copper punch $8 \mathrm{~cm}$ in length, triangular transversal section, pointed on both ends (5) [Figure 4.C.5].

Molluscs: 9 molluscs, among them 2 Patella (18) [Figure 4.C.18]. The remaining molluses are not, according to the image identified precisely, 6 small Pectens (or Cardium), 1 Pecten? (16. 17) [Figure 4.C.16-17]

Pottery: 1 hemispherical bowl, $10.5 \mathrm{~cm}$ in diameter at the rim, with $4.5 \mathrm{~cm}$ in height, found next to the passage portal. Fragments of black-shaded vessels. Fragments of a large and thick vessel with strongly micaceous fabric. Fragments $1 \mathrm{~cm}$ thick with plastic applications (15) [Figure 4.C.15].

In the passage: Fragment of a bovid mandible with teeth.

Fragments of six Roman tiles.

All objects belong to Don J. Viera, Antequera; except $n^{\circ} 13$ : property of Mr. Anson, Antequera. $N^{\circ} 15$ property of W. J. Hemp, England. 
Grave goods according to Mergelina, $\mathrm{N}^{\circ} 15$ after Hemp.

Cup-marks: a stone in the antechamber is covered with a great amount of cup-marks. On various of the stones near the passage slab cup-marks are found too, 3 $-5 \mathrm{~cm}$ in diameter and up to $3 \mathrm{~cm}$ deep.
Finds in the territory of Antequera. According to Gómez-Moreno [Martínez], for many years, handthrown pottery objects, flint blades and stone axes of serpentine (easy to come by in the province) of the same type discovered at the Viera Cave - have been found at Cerro de Marimacho, near the graves.

1) Finds report by Gómez Moreno [Martínez]; exact count of the additional bone finds near them, Arquitectura tartesia 93 Anm. 1; also Mergelina, Necrópoli tartesia 83.

2) Góngora, Antigüedades de Andalucía 89. 90.

$\left.{ }^{3}\right)$ If Mergelina's sketch is not clear a. a. O. 58 research on this tomb should be taken in general terms.

$\left.{ }^{4}\right)$ Anta da Arruda, Anta da Capella. 


\section{SUPPLEMENTARY INFORMATION 2: SPANISH TRANSLATION OF THE ANTEQUERA DOLMENS PROVIDED BY GEORG AND VERA LEINER}

\author{
IV. Provincia de Málaga.
}

Los famosos dólmenes de Antequera son hoy en día los únicos explorados en la provincia.

Grupo 1. Antequera.

La ciudad de Antequera se encuentra a 500 metros sobre el nivel del mar en la rica Vega del Guadalhorce. La Sierra de Abdalajís, sobre cuyo norte suben pintorescas estribaciones montañosas coronadas por una antigua fortaleza (Lám. 97,2) [Figura 1.A], separa la Vega del litoral de Málaga. Tres caminos bajan hoy hasta la costa: uno sigue el curso del Guadalhorce, el único río que atraviesa la Cordillera Bética y permite el acceso al sur sin cruzarlo. Los otros dos llegan hasta el mar después de atravesar la Sierra cruzando corrientes de río menores. Así, Málaga se convierte en el puerto natural de la Vega de Antequera y se cree que, al igual que en Almería, en la época prehistórica pudo haber interacción entre la costa y el interior. Sin embargo, al contrario que en el sureste, en Málaga no se ha encontrado hasta ahora ningún rastro de asentamientos costeros.

La región de Antequera le debe su riqueza a un suelo muy productivo y a un clima bastante suave, además de a su estratégica posición como punto de encuentro de los caminos que unen Sevilla, Granada y Málaga. El ferrocarril que lleva los minerales de Linares al mar sigue funcionando todavía hoy en día, pasando por Antequera hasta llegar a Málaga, por lo que es posible que el comercio fuera un factor principal del florecimiento de Antequera en tiempos prehistóricos; sobre todo porque en sus alrededores más inmediatos solo se encuentran metales. Los tres enormes sepulcros megalíticos que se encuentran en el entorno inmediato de la ciudad son testigo de ese florecimiento, la Cueva de Menga, Viera y la Cueva del Romeral, las cuales se encuentran entre las más conocidas e importantes de la Península Ibérica. Y probablemente no sean las únicas: Mergelina informa además de otras colinas que podrían ser artificiales.

La literatura que existe sobre los tres sepulcros se resume a continuación, mencionando qué sepulcros se tratan individualmente. Todos los autores de antes de
1905 conocían solo la Cueva de Menga. Las publicaciones más importantes están marcadas con un asterisco.

1. Fuentes antiguas con informes originales y planos:

R. Méndez Silva, Población general de España: sus trofeos, blasones y conquistas heroicas (1675).

R. Mitjana, Memoria sobre el templo druida descubierto en la ciudad de Antequera (1847).

C. Lucas, Comptes-rendus de la Soc. Franç. de Numism. et d'Arch. 2, 1870, 277. 319.

E. Harlé, Matériaux pour l'Histoire de l'Homme 1887, 80.

E. Cartailhac, Les âges prehistoriques de l'Espagne et du Portugal (1886) 186 (Plano de Nodet).

2. Fuentes nuevas con informes originales y nuevas incorporaciones:

*R. Velázquez Bosco, Cámaras sepulcrales descubiertas en término de Antequera. Rev. de Archivos, Bibliotecas y Museos 9, 1905, 413 (Romeral, Viera).

*M. Gómez-Moreno [Martínez], Arquitectura tartesia. La necrópolis de Antequera. Bol. de la Real Acad. de la Historia 47, 1905, 81-132 (Menga, Romeral, Viera).

P. Paris, Promenades archeologiques en Espagne: Antequera. Rev. Arch. 8, 1919, 239-271 (Menga, Romeral, Viera).

A. de Mortillet, Le dolmen d'Antequera. Assoc. Franç. pour l'Avancement des Sciences, 44' Session. Strasbourg 1920 (1921) 475 ss. (Menga).

*C. de Mergelina, La necropoli tartesia de Antequera. Soc. Esp. de Antrop. Etn. y Prchist. 1. Mein. 4, 1921/22, 37 ss. (Menga, Romeral, Viera).

3 Fuentes con explicaciones de la clasificación comparativa de los sepulcros:

H. Obermaier, Die Dolmen Spaniens. Mitt. d. Anthr. Ges. Wien 50, 1920, 114 ss. - El dolmen de Matarrubilla (1919) 26 ss.

J. R. Melida, lberia arqueologica anteromana. Discurso de recepcion en la Real Academia de la Historia (1906) $31-40$.

W. J. Hemp, The Passage Graves of Antequera and Maes Howe, Orkney. The Antiquaries Journal 14, 1934, 404 ss.

E. Thurlow Leeds, The Dolmens and Megalithic Tombs of Spain and Portugal. Archaeo logia 70, 1920, 201 ss. 
J. Déchelette, Manuel I 149.

N. Aberg, Civilisation Eneolithique (1921) 20.

Cueva del Romeral.

Lám. 55. 58; Imágenes: Lám. 98-102.

Situación: desde la entrada de La Cueva de Menga se ve directamente el característico perfil rocoso de la Peña de Los Enamorados, y por detrás surgen los picos de la Sierra de Archidona. Delante de la primera se eleva, a unos 2 kilómetros de la Cueva de Menga, en medio de la llanura, una colina artificial que recibe el nombre de Cerrillo Blanco debido a su color (Lám. 98,3) [Figura 1.B]. En esta colina tumular, los hermanos Viera descubrieron el sepulcro de cúpula Cueva del Romeral en agosto de 1904. Desde Antequera se llega a la tumba por la carretera de Archidona, desde la que hay que tomar la desviación al norte a la altura de la fábrica de azúcar. Tras pasar las vías del tren, nos encontramos inmediatamente con el túmulo (Lám. 98,1) [Figura 2.A]. El diámetro del túmulo es de unos 85 metros, su altura, que aumenta hacia al norte debido al hundimiento del terreno, es de 8 a 10 metros. Debido a la erosión, la cima se encuentra aplanada hoy en día. Recientemente se han abierto unas galerías que han demostrado el carácter artificial del túmulo, ya que se encontraron manchas de tierra negra y restos orgánicos mezclados con arena, barro y guijarros. Según P. Paris, en la zona norte del túmulo se encuentra una segunda construcción, "una especie de galería inclinada que desciende pronunciadamente y no acaba en una cámara. Desde ella se desvía hacia la izquierda un pequeño corredor, y a la derecha, cerca de la entrada, otro corredor detrás del cual se puede ver una habitación mayor". Todavía no se ha podido especificar si se trata de galerías de los saqueadores o si realmente eran parte de la construcción original.

Forma y construcción: sepulcro de corredor con dos salas con forma de cúpula, circulares, contiguas y alineadas, construidas con mampostería pequeña. La longitud total del sepulcro hasta el punto de intersección del nivel del suelo y el borde del túmulo funerario es de $44 \mathrm{~m}$. De estos, corresponden a las cámaras $10 \mathrm{~m}$, a la zona de acceso $34 \mathrm{~m}$.

Orientación: S. $25^{\circ} \mathrm{O}$.

Recinto de entrada:

Antecámara exterior: en los primeros textos sobre la tumba escritos por Velázquez Bosco y Gómez-Moreno [Martínez] en el año de su descubrimiento, a $25 \mathrm{~m}$ de la entrada de la cámara, todavía había "una losa alta enterrada y otras piedras más pequeñas que no son suficientes para definir la forma de la puerta". Los restos de esta parte de la construcción están situados en ambas plantas en el lado izquierdo, constituyéndolos una losa perpendicular a la pared longitudinal en el lado izquierdo de la misma altura que el corredor, que está opuesta, según Gómez-Moreno [Martínez], a un ligero saliente de la pared que va en paralelo a ras de esta. A $1,50 \mathrm{~m}$ por fuera de este lugar se encuentra otro estrechamiento del corredor mucho más pronunciado por la izquierda. De esta manera, se delimita un espacio cuadrado cuya pared de la izquierda está ocupada en su totalidad por una losa. Probablemente se trate de los restos de una antecámara exterior con la misma forma que la de la Cueva del Vaquero y de los dólmenes de Alcalá. Fuera de la posición de esta losa, la entrada se encuentra destruida y sepultada.

Antecámara principal: el espacio principal de acceso a la construcción es una galería de $23 \mathrm{~m}$ de longitud que se extiende sin subdivisiones desde la puerta exterior hasta el corredor de la sala de la cúpula. Se amplía ligeramente en anchura hacia el interior del sepulcro, de $1,70 \mathrm{~m}$ a $1,80 \mathrm{~m}$. Las medidas aportadas por los diferentes autores difieren unas de otras debido a la irregularidad de las losas de la pared.

Medidas de la altura del corredor: Gómez-Moreno [Martínez] determina la altura en 2,0 m. Su alzado muestra alturas uniformes. Según los informes de Mergelina, quien establece la altura en 1,85 m, la altura del corredor aumenta ligeramente hacia la cámara. Nuestras medidas, basándonos en esos datos, serían:

- 14,50 m de distancia desde la entrada de la cámara $=1,60 \mathrm{~m}$,

- 10,0 m de distancia desde la entrada de la cámara $=1,80 \mathrm{~m}$,

— 6,20 m de distancia desde la entrada de la cámara $=2,0 \mathrm{~m}$.

Estas medidas se han tomado desde el suelo actual. En la parte cubierta de la entrada el nivel actual del suelo se corresponde con el original. La ligera disminución de la altura del corredor debe haberse producido por la caída de la cubierta.

Las paredes están construidas con mampostería pequeña y sobresalen ligeramente - 0,28 m: $10 \mathrm{~m}$ desde la entrada hasta 0,37 m: $6 \mathrm{~m}$ desde la entrada. Este saliente se reparte por toda la altura de la pared, de manera que la curva se desvía solo un poco de una línea recta inclinada hacia delante (Lám. 55 a.b) [Figura 3]. El material de construcción de las paredes se compone de lajas grises calizo-margosas con incrustaciones de cristales 
dolomíticos negros. Los materiales son de una cantera diferente a la de los materiales de Cuevas de Menga y Viera. Parcialmente, se disponen en capas regulares, en otras partes se han introducido lajas gruesas y pequeños bloques (g) [Figura 3]. En general, la construcción es menos cuidadosa que la de la cámara. El grosor de las lajas varía entre 0,05 y $0,15 \mathrm{~m}$; el ancho es muy diferente, la longitud - en general entre 0,40 y $0,50 \mathrm{~m}$ se pudo determinar en algunas de las partes destruidas en hasta 1,0 m. Bajo las cobijas se encuentran las lajas de mayor longitud y, en ocasiones, también de mayor grosor. Estas están unidas con arcilla, cuyas capas, especialmente a mayor profundidad de la pared, alcanzan parcialmente el espesor de las lajas de piedra. Las capas de arcilla no sobresalen hasta la superficie de la pared. Los espacios intermedios están rellenos con fragmentos de lajas y gravilla, que, según Mergelina, solo fueron introducidos una vez completada la pared. La pared parece mucho más irregular que la de la cámara de Matarrubilla y la de la cámara lateral de Cueva del Vaquero. En áreas deterioradas aún podríamos detectar a 1,0 m de profundidad, lajas dentro de una gruesa capa de arcilla; a continuación, una masa de guijarros, arcilla y tierra forma la transición a la colina artificial, a la cual se le han introducido piedras a una profundidad de 2,0 metros en un punto muy deteriorado de la pared.

La cubierta se compone de grandes losas sin tratar con una anchura de al menos 1,50 $\mathrm{m}$ y un grosor de 0,40 - 0,50 m. En los socavones deteriorados de la pared se podía constatar un saliente lateral de aproximadamente 1,0 m, lo que corresponde a una longitud de la piedra de casi 4,0 m. La cubierta se ha mantenido intacta en los $15 \mathrm{~m}$ de longitud desde la entrada de la cámara, a excepción de una rotura del tamaño de una cobija a unos $10 \mathrm{~m}$ de distancia. En total hay 10 cobijas in situ, de las cuales cuatro están rotas debido a la presión de la tierra. Las cobijas están situadas parcialmente en diagonal con respecto al eje longitudinal, lo cual no se observa en el plano de Mergelina. El suelo se pavimentó encajando losas de diferentes tamaños. Los espacios intermedios se rellenaron con piedras pequeñas.

La conservación de las zonas de entrada es bastante mala: en toda su longitud solo perdura la mitad inferior del muro. En la parte en la que falta la cobija, hoy en día se ha abierto una entrada con forma de pozo. La capa de pared exterior también se encuentra completamente disgregada en el espacio cubierto.

Cámara principal: 4,80 x 5,24 m de diámetro, la altura desde el suelo actual es de $3,80 \mathrm{~m}$, la abertura superior de la cúpula es de 2,20 m de diámetro. Altura original según Gómez-Moreno [Martínez]: 4,0 m.
La sala de cúpula casi circular transmite una impresión bastante armónica debido a sus equilibradas medidas. El saliente de la pared mide en el lado izquierdo 1,42 m. La curva de la bóveda es bastante recta, sobre todo en su mitad superior; la mayor desviación de la recta a $1,70 \mathrm{~m}$ sobre el suelo es de solo $0,24 \mathrm{~m}$. La bóveda con forma de colmena que muestra la vista de perfil de De Mergelina no corresponde con la realidad. La cámara está construida en mampostería pequeña como el corredor (Lám. 100,2) [Figura 2.E]. La técnica de construcción es la misma, aunque la selección de lajas es más cuidadosa. En las cuatro capas inferiores se encuentran, en una línea regular, lajas de una misma resistencia, por encima solo se reconocen las líneas parcialmente. El grosor de las lajas varía ligeramente, las más robustas miden aproximadamente $0,15 \mathrm{~m}$. El ancho asciende a 0,21 - 0,40 m. La longitud de las lajas en la capa de la pared frontal generalmente no es discernible; en un punto a $0,65 \mathrm{~m}$ detrás de la pared frontal descubrimos un segundo muro circular. Aquí las lajas también se encontraban embutidas en arcilla, cuyas capas coincidían con el grosor de las lajas. En general, las paredes parecen bastante planas y lisas.

El extremo circular superior de la cúpula se compone en parte de las dos capas superiores, como también se mencionó ya en el corredor, de lajas algo más gruesas; bloques individuales de 0,20 a $0,40 \mathrm{~m}$ de grosor $\mathrm{y}$ hasta $0,90 \mathrm{~m}$ de ancho se alternan aquí con mampostería normal. Probablemente no sea casual y sirva, como el "cuello" pronunciado que presentan otros dólmenes de cúpula de Andalucía, para mayor estabilidad, de manera que las lajas que se encuentran directamente bajo la cobija retroceden sobre los bloques que tienen bajo ellas en lugar de sobresalir. La cúpula está cerrada con una cobija de "piedra caliza silícea sólida, pardusca", cuyas medidas según Gómez-Moreno [Martínez] son de 6,0 m de diámetro y $0,80 \mathrm{~m}$ de grosor (Lám. 102,4) [Figura 2.D]. Para la dimensión de la cámara, la línea de base de la sala supera la cobija en relativamente poco. Al contrario que en Pastora, Matarrubilla e incluso Vaquero, aquí la cobija está centrada sobre la apertura de la cúpula, una construcción incomparablemente más artística.

El suelo de la cámara principal está pavimentado como el recinto de entrada principal. En la actualidad, aparte de varias cavidades similares a nichos en la derecha, gran parte de la pared se ha deteriorado.

Cámara secundaria (Lám. 100,1) [Figura 2.G]. A la cámara principal, a través de un corredor, cuyo excepcional sistema de construcción se discutirá más adelante, se conecta un segundo espacio menor en forma de cúpula. El acceso y la cámara secundaria no se 
encuentran en la prolongación del eje longitudinal del resto de la estructura del sepulcro, más bien se desvía del eje unos $10^{\circ}-0,50 \mathrm{~m}$ en la pared trasera de la cámara principal - hacia el sur. La cámara secundaria construida con la misma técnica que la cámara principal cuenta con 2,34 $\mathrm{m}$ de diámetro y 2,40 $\mathrm{m}$ de altura. La apertura de la cúpula mide $0,90 \mathrm{~m}$; el voladizo es por lo tanto de aproximadamente $0,70 \mathrm{~m}$. El remate que constituye la terminación de la cúpula sobresale, como es visible en una parte destruida, 1,20 m más allá del borde de la bóveda; por lo que debería ser un poco más grande que el indicado en el alzado de Mergelina. En la cara inferior de la cobija hay algunas líneas incisas, de las cuales un triángulo con una línea central, cruzada por una línea transversal, parece ser artificial (c) [Figura 3]; una impresión que se confirma por comparación con hendiduras de diseño similar en restos de losas de Alcalá 1 (Lám. 77, Sepulcro 1 b. c. d).

El suelo del acceso a la cámara secundaria se encuentra a $0,70 \mathrm{~m}$ de altura sobre el de la cámara principal y según Mergelina se mantiene en la cámara secundaria a ese nivel; por el contrario, Gómez-Moreno [Martínez] y Velázquez Bosco sostienen que el suelo desciende nuevamente detrás de la puerta, de manera que la parte inferior de la losa que se describe a continuación tiene la misma altura que el suelo del acceso. Estas partes del sepulcro estaban llenas de escombros y no las hemos examinado. La totalidad de la mitad trasera de la cámara está ocupada por una gran losa de piedra caliza de 0,30 $\mathrm{m}$ de espesor, que se encuentra 0,20 $\mathrm{m}$ más alta que el suelo de la cámara y está dispuesta empotrada en la pared. Su lado frontal está cortado o roto en el medio. En la cara superior trabajada son visibles algunas manchas que podrían haber resultado de la descomposición de sustancias orgánicas. La cámara se encuentra considerablemente deteriorada en algunas partes, y en el lado derecho hay dos grandes agujeros en forma de embudo.

Corredores y puertas: tanto entre la galería de acceso y la cámara principal como entre ésta y la cámara secundaria se encuentran portales ingeniosamente erigidos, en principio construidos de manera similar.

Puerta 1 y corredor hacia la cámara principal (i. k.) (Lám. 99,1) [Figura 2.B]. Dos jambas de sección transversal casi cuadrada de una altura de $1,60 \mathrm{~m}$, empotradas en las paredes del corredor, sobresalen unos 0,30 o $0,45 \mathrm{~m}$. Dentro de estas jambas, retiradas $0,50 \mathrm{~m}$ hacia la cámara, dos losas de 0,25 $\mathrm{m}$ de espesor de igual altura definen la abertura de la puerta, cuyo ancho libre en el lado del corredor es $0,69 \mathrm{~m}$, en el lado de la cámara $0,78 \mathrm{~m}$. Las losas se inclinan ligeramente hacia dentro, de manera que el hueco de la puerta se estrecha ligeramente hasta la parte superior $-0,10 \mathrm{~m}-$ en forma trapezoidal. En el lado de la cámara estos dos bloques se encuentran achaflanados en su mitad superior. Esto corresponde al deseo de no interrumpir la curvatura de la pared por los bordes rectos verticales del marco de la puerta en su altura total de 1,60 m. Como resultado de este chaflán fue posible que, ya a unos 0,80 $\mathrm{m}$ por encima del suelo de la cámara (mediante la pequeña mampostería colocada en los bordes biselados), comenzara la curvatura en la puerta de acuerdo con la pared, que también incluía el correspondiente dintel superior que sobresalía (Lám. 101,1) [Figura 2.C]. Mucho más claramente aparece este esfuerzo, como ya se anticipó, en la puerta del interior de la cámara secundaria; aquí, justo por encima del suelo de la cámara, comienza el chaflán de las losas de los pilares de la puerta $y$, por tanto, comienza la bóveda de pequeña mampostería. Además, el dintel superior no solo avanzó como en la cámara principal hacia la curva de la bóveda, sino que se adaptó exactamente al borde achaflanado (Lám. 100,1) [Figura 2.C].

El portal está cubierto con una losa que es visible tanto en la cámara como en el corredor como dintel de la puerta. Se proyecta hacia la cámara a aproximadamente 1,0 m en ambos lados más allá del hueco de la puerta; entre ella y las jambas se ha interpuesto una capa de mampostería, de construcción bien planeada y no desordenada, como asume P. Paris, ya que la misma técnica aparece en la Cueva de Viera. Entre el dintel y la cobija del corredor, situada unos $20 \mathrm{~cm}$ más alta, se encuentra también la mampostería. Las losas más gruesas que sobresalen por los lados forman aquí una construcción de descarga.

Corredor y puerta a la cámara secundaria (d. e.) (Lám. 99, 2) [Figura 2.F]. Probablemente para interferir lo menos posible en la impresión unificada de la cubierta abovedada y no interrumpirlo con las jambas verticales de la puerta, se dejó una simple abertura en la pared a la entrada del corredor desde la cámara principal a la cámara secundaria, que también se estrecha hacia arriba en forma trapezoidal con arreglo a la disminución de la bóveda. Esta abertura, hoy de 1,90 $\mathrm{m}$ de altura, parece haber surgido más abajo, aunque debe tenerse en cuenta al evaluar su forma que el umbral de la entrada a la cámara secundaria también se redondea ligeramente en la Cueva del Vaquero.

La primera sección del corredor [a la segunda cámara], de 1,20 $\mathrm{m}$ de profundidad, está construida en pequeña mampostería y se ensancha hacia dentro de 0,70 a 1,0 m y está pavimentada. Le sigue después el 
verdadero vano de la puerta, cuyas jambas, como en el primer corredor, se construyen con los bordes laterales de dos losas, las cuales delimitan las paredes de la parte trasera del corredor. Estas losas sobresalen a los dos lados en 0,12 o $0,18 \mathrm{~m}$ en el corredor y le proporcionan a la puerta una anchura de 0,68 m. Hacia la cámara secundaria la sección de este espacio también se ensancha de nuevo trapezoidalmente hasta 0,76 metros.

La cubierta de este corredor [a la segunda cámara] es, en parte debido a su mayor longitud, pero en parte, debido al conocimiento de que este punto de construcción entre las dos cúpulas requería una estabilidad de extraordinaria seguridad, mucho más importante que la del primer corredor. Las tres losas utilizadas para techarlo se encuentran a diferentes alturas, los espacios intermedios se rellenaron con pequeña mampostería. De esta manera se obtiene una distribución de la presión. Al fondo como dintel de la puerta, se encuentra la cobija interior, este tramo es, por lo tanto, más bajo. En la cámara esta cobija está ligeramente retraída en la pared y es posible que originalmente estuviera completamente cubierta con un revoco. La descarga de la bóveda sin una viga horizontal visible se logra gracias a que esta losa está ligeramente inclinada y desaparece en la pared izquierda, mientras que una losa superpuesta y ligeramente más delgada se superpone oblicuamente en un ángulo obtuso con respecto a la primera desde la izquierda. Una construcción similar se puede encontrar en la Cueva del Vaquero.

La Cueva del Romeral es justamente considerada como el ejemplo más bello de construcción de cúpula prehistórica conservado de la Península. De los sepulcros andaluces y sur portugueses de construcción similar, ninguno puede competir con ella ni en la magnificencia de todo el complejo ni en la ponderada y minuciosa ejecución de los detalles arquitectónicos. Este esmero en la construcción es probablemente la razón por la que este monumento único se ha preservado casi completo hasta nuestros días.

Más allá del conocimiento de los fundamentos de la arquitectura, se percibe en todas partes una voluntad artística unificada. El interés por la bóveda y la línea curva, la mayor omisión posible de los ángulos rectos no solo se nos aparece en las construcciones de las puertas de las salas en forma de cúpulas que tratamos, sino también en las ampliaciones y estrechamientos trapezoidales de los corredores. Las ideas que nos vinieron a la mente cuando tomamos en cuenta los detalles de la construcción del sepulcro se explican con gran detalle y entendimiento en el informe de Mergelina.
Informe de excavación y hallazgos: cuando fue descubierto, el sepulcro ya había sido saqueado y rellenado con tierra suelta hasta una gran altura. En la cámara, el relleno era de 0,80 metros de alto: se halló una capa superior de tierra sin rastros humanos, debajo una capa más oscura y compacta con capas de cenizas negras, probablemente mezcladas con restos orgánicos, en el medio una gran cantidad de huesos humanos machacados, algunos pedazos de vasijas y dos fragmentos de conchas de mar de las especies Litódomos y Mactra. Hasta donde puede juzgarse por los fragmentos, los huesos pertenecen a individuos pequeños. Ningún cráneo, pero sí dos mandíbulas y un fragmento de una tercera. En la cámara secundaria se encontró bajo la losa del suelo un cuerno, como de un toro joven. En el corredor de acceso aparecieron algunos huesos de animales pequeños, también mucha cerámica, además de la del momento de la construcción de los sepulcros, el cuello de una hidria romana y fragmentos de ladrillos. Ningún hallazgo en el corredor intermedio.

De la cerámica, los siguientes fragmentos son dignos de mención (Lám. 58, Sepulcro 1) [Figura 4.A]:

1) Del corredor: vaso semiesférico de $0,10 \mathrm{~m}$ de altura y $0,18 \mathrm{~m}$ de diámetro y de entre 1 y $3 \mathrm{~cm}$ de espesor, de arcilla negra con algunas tonalidades rojizas e incrustaciones de cuarzo; fue encontrado en el corredor cerca de la entrada (1) [Figura 4.A.1]. Fragmento de una vasija con una ligera oscilación, pared más alta, y $7 \mathrm{~cm}$ de altura, $11 \mathrm{~cm}$ de espesor, amarillenta, rotura negra (2) [Figura 4.A.2]. Fragmento de otra vasija con una pared recta cónica. Pedazos del borde de una vasija grande de $7 \mathrm{~mm}$ de grosor, negra, pulida, con una acanaladura ligeramente desplazada bajo el borde (3) [Figura 4.A.3]. Fragmentos de borde, de arcilla fina bien cocida, negra, pulida, con $7 \mathrm{~mm}$ de grosor con un borde curvado y saliente (5) [Figura 4.A.5]. Dos piezas de cerámica, una triangular y la otra elíptica, con señales de haber sido frotadas; de tono amarillento rojizo.

2) De la cámara: todas las cerámicas de la cámara están sin decorar, bien cocidas, completamente ennegrecidas y de pasta fina y compacta, el exterior bruñido. Algunos fragmentos son de $7 \mathrm{~mm}$ de espesor. Reconocible: pedazos del borde de un cuenco grande semiesférico con borde recogido (6) [Figura 4.A.6]. Pedazos de borde de una vasija de cuello estrecho y de borde saliente.

Enumeración de la cerámica según Mergelina a. a. 0. 84. 85 .

Los objetos en la colección de los Srs. Viera, Antequera $\left.^{1}\right)$. 
Cueva de Menga.

Lám. 56. 58; Imágenes: Lám. 97. 98. 104. 105.

Situación: El sepulcro se encuentra al este a las afueras de la ciudad de Antequera, en el camino hacia Archidona. Desde éste se ramifica a $1 \mathrm{~km}$ de las últimas casas, donde se desciende a la vega, un sendero hacia el norte desde donde el sepulcro se encuentra aproximadamente a $20 \mathrm{~m}$ de distancia. La gran cobija de la entrada es visible desde el camino (Lám. 98,4) [Figura 5.A]. El terreno desciende bastante abruptamente unos $10 \mathrm{~m}$ desde la entrada hasta la vega (Lám. 97,1) [Figura 1.C].

Exploración: No se sabe cuánto tiempo lleva abierto el sepulcro. La primera nota que se ofrece al respecto la proporciona Mergelina con un escrito de R. M. Silva (1675). En el año 1842, R. Mitjana encontró el sepulcro ya completamente saqueado, por algún tiempo fue utilizado como espacio económico. El hecho de que fuera conocido por el pueblo desde hacía bastante tiempo lo prueban las leyendas vinculadas a él (P. Paris a. a. O. 244). La primera noticia científica venía de R. Mitjana, un arquitecto de Málaga; sobre las investigaciones posteriores se da información en la p. 173. A día de hoy, todavía no queda claro el origen del nombre Menga (¿Mengal?). De las diversas conjeturas, solo una parece estar razonablemente bien fundamentada, la que lo relaciona con una vieja canción gitana vinculada con el menhir de Baena, y en ambas se relaciona con las ideas legendarias de un gigante $^{2}$ ).

Conservación: La construcción es tan buena como completamente conservada. Tal vez falten algunos ortostatos y cobijas en la parte exterior de la entrada. Detrás de la piedra frontal, el túmulo del sepulcro está desmontado, encontrándose la última [losa] descubierta tal como la cobija exterior. La esquina superior derecha de la losa de cabecera tiene una rotura de aproximadamente de 1 metro cuadrado, probablemente obra de los saqueadores, que pudieron penetrar aquí fácilmente a través del túmulo funerario.

Orientación: E. $30^{\circ} \mathrm{N}$.

Forma y construcción: Sepulcro de corredor con cámara oval larga. Longitud total de $25 \mathrm{~m}$, ancho total $5,50 \mathrm{~m}$, altura actual: de 2,70 hasta $3,20 \mathrm{~m}$.

Cámara: La cámara se distingue más claramente del corredor que en el caso de otros sepulcros de corredor largo y galerías del suroeste. El sepulcro se puede conectar a otros sepulcros del sureste concretamente al grupo de las cámaras trapezoidales con paredes completamente oblicuas. Longitud de la cámara: 16,25 m, construida con 7 ortostatos cada una [cada pared], una losa de cabecera y cinco cobijas.

La losa de cabecera de 3,50 m de anchura está colocada entre las paredes laterales (modo de construcción portugués). Los dos ortostatos contiguos están ligeramente inclinados hacia fuera; la ampliación de la cámara comienza aquí. Desde las paredes de la cámara, el lado izquierdo discurre en una curva regular, ligeramente arqueada; la posición de las losas en el lado derecho es menos arqueada y más irregular. La anchura mayor de la cámara - 5,40 m - se encuentra aproximadamente a 5,50 $\mathrm{m}$ desde la losa frontal al último pilar. Desde aquí, el espacio se estrecha gradualmente hasta 2,25 metros en la entrada.

Corredor: el corredor comienza con 3,05 m de anchura junto a la cámara; los cantos laterales de los últimos ortostatos de la cámara sumamente anchos están libres en su mitad en el lado del corredor y forman las jambas de la puerta. La separación entre la cámara y el corredor se muestra más claramente en la imagen de la Lám. 104,2 [Figura 5.D], como se puede ver a primera vista en el plano. Esta configuración de la entrada a la cámara es semejante a la de algunos de los sepulcros de corredor atlánticos de tipo poligonal; la inclusión de los bordes de las piedras en la configuración arquitectónica requiere el uso de bloques gruesos, que son raros en el sureste como ortostatos. Más allá de esta razón puramente técnica está, sin embargo, la ausencia de una losa transversal de entrada que atraviese la pared vertical, otra prueba de la fuerte relación con las cámaras poligonales portuguesas.

Del corredor se conservan 5 ortostatos de cada pared. La longitud total de esta parte de la construcción es hoy en día de $8,70 \mathrm{~m}$, su ancho se reduce hacia la entrada exterior a 2,0 $\mathrm{m}$ al exterior del cuarto ortostato. Con el quinto, hoy último ortostato, se abre de nuevo una ampliación del corredor. No está claro si esta colocación oblicua de los ortostatos exteriores del corredor proviene de la construcción primitiva. Por lo general, se supone que las losas se desplazaron de su posición más tarde. Sin embargo, las posibles comparaciones de la ampliación del corredor como atrio son múltiples en este tipo de sepulcros. Una exploración de la construcción del túmulo quizás podría ofrecer aclaraciones sobre esta cuestión. De acuerdo con el diseño de la obra, es posible y se puede suponer una longitud primitiva mayor de la construcción en 1 o 2 ortostatos. La proporción de la cámara y la longitud del corredor se mantendría también, incluso con tal ampliación, en aproximadamente 4:3. El corredor es, por tanto, notoriamente corto si se compara con los sepulcros de 
Romeral y Viera y con los demás grandes sepulcros de Andalucía y del sur portugués. Con esta planta nos mantenemos enteramente en el terreno de la arquitectura del sudeste.

Volveremos a una posible subdivisión del corredor en la construcción del sepulcro.

Mergelina dibuja en el plano una segunda línea, que coincide con los puntos inferiores de los ortostatos en general y que solo en la zona frontal interior se encuentra a aproximadamente a 1,0 m. Esta línea representa, según su explicación, un surco de 0,20 m de ancho localizada en las cobijas, que él considera como un boceto de la construcción. La ejecución sería tan meditada que en la preparación de la cubierta - que probablemente requiriese de manera previa la unión de las piedras fuera de la tumba -, la planta de la cámara se había trazado en la parte inferior de la cubierta. La cámara se habría planeado originalmente algo más corta. Esta ranura de unión se puede observar en algunas cobijas (Lám. 104, 1 derecha arriba) [Figura 5.E]. En las paredes laterales no está completamente claro cómo se puede ver la ranura de la curva dibujada por Mergelina, ya que, por la inclinación hacia delante de los ortostatos, la base de la planta se encuentra considerablemente más atrás del punto de intersección entre la cubierta y la pared. También parece singular que tal boceto, que al fin y al cabo daría testimonio de una arquitectura bien planificada, anticipa las irregularidades accidentales de la dirección de la pared. Parece necesario comprobar estas observaciones. En nuestra opinión, también sería concebible que un boceto de la forma de la cámara en la cubierta hubiera tenido el propósito de evitar el desplazamiento lateral excesivo de la cubierta, cuando se dispusiera esta última.

Construcción: La construcción sepulcral está integrada en una colina natural, en cuyo el lado noreste está cortada tan cerca de su cumbre, que la cobija trasera de la cámara está a la misma altura que ésta (Lám. 56) [Figura 6]. El subsuelo de la colina está compuesto de piedra caliza, que es fácil de trabajar. La profundidad de la excavación en la roca no está determinada con certeza. Según Mergelina, la zanja en la roca podría llegar hasta el extremo superior de los ortostatos, lo cual resulta verosímil según casos análogos de Gandul.

En la literatura más antigua se afirma repetidamente que la tumba se encontraba en una colina artificial. Esta suposición probablemente se base en una investigación de P. Paris, quien descubrió tras los ortostatos un muro de 0,60 m de grosor. De hecho, estas dos observaciones no se contraponen la una a la otra. La construcción probablemente se asemeje a la de las galerías megalíticas de Gandul, donde los ortostatos tampoco se encuentran directamente contra la pared de la zanja, sino que aproximadamente a $0,50 \mathrm{~m}$ de distancia están exentas de este soporte y el espacio intermedio está relleno con piedras y paquetes de arcilla. Los restos del túmulo que se conservan sobre la cámara a 3,0 $\mathrm{m}$ de altura, hoy aplanados en la parte superior, también se componen de arcilla y capas de piedras.

Los ortostatos, con excepción de la losa de cabecera que está en vertical, están ligeramente inclinados, de manera algo más pronunciada en la pared derecha, en un promedio de 0,35 metros. Se necesitan investigaciones exactas sobre la longitud de los ortostatos, su fijación al suelo ${ }^{3}$ y el suelo original de la cámara. Mitjana indica que los ortostatos alcanzan hacia abajo del suelo de la cámara 1,0 m - 1,5 m. El alzado de Mergelina permite aceptar que el suelo marcado por él - en la piedra de cabecera, de acuerdo con ello, 3,20 m de altura de la cámara- es el original, ya que aquí se fija la cimentación de los pilares y de la losa de cabecera. Gómez-Moreno [Martínez] supone en 1905 un relleno de tierra en el sepulcro de aproximadamente 0,67 - 1,30 m. La comparación de los planos de Gómez-Moreno [Martínez] y de Mergelina, así como las fotografías de los años 1905 y 1934, muestran que el suelo de la cámara de aquel entonces y el de hoy se encuentra todavía al mismo nivel. La excavación del año 1904 en la que se encontró un hacha de piedra a $0,50 \mathrm{~m}$ de profundidad bajo el suelo, sugiere que el suelo original estaba en realidad más bajo de lo que muestra el alzado de Mergelina.

Por lo tanto, las siguientes cuestiones aún permanecen sin resolver: ¿Se asienta el acuñamiento de los pilares y los ortostatos realmente a los 3,20 m por debajo de la cubierta? ¿Dónde se encuentra el subsuelo rocoso natural?

Tan solo la determinación de estos hechos puede proporcionar información sobre las dimensiones de altura de la cámara, así como sobre el ascenso o caída del suelo de la cámara. En un estado más bajo de este último, también sigue en cuestión el ahondamiento del suelo en la sección del corredor más cercana a la cámara, según Mergelina 0,45 $\mathrm{m}$ rebajado en la toba volcánica. La altura de la tumba disminuye hasta el extremo exterior del espacio cubierto alrededor de 1,20 m por la caída regular y ligera de la cubierta.

La cámara está cubierta con cuatro losas, la antecámara con otra losa, que es equivalente en tamaño y grosor a las de la cámara, casi superándolas. El cambio habitual de cobijas de gran tamaño a menores, que simultáneamente están trabajadas menos cuidadosamente en la mayoría de las prolongaciones de los corredores, aquí no se observa, por lo que esta sección 
de la sala puede ser abordada más bien como antecámara. De los cuatro ortostatos del exterior del espacio cubierto, Mergelina dibuja el interior del lado derecho a la misma altura que la pared de la antecámara, sin embargo, solo tiene 1,50 $\mathrm{m}$ de altura y no parece estar roto. Los tres ortostatos restantes cuentan con solo $0,80 \mathrm{~m}$ de altura. Todos están menos elaborados y están colocados en vertical. La cubierta original sigue siendo cuestionable, quizás se trate del límite de una antecámara abierta, lo que también indica el diseño de la planta.

Material, tratamiento: El material de construcción es piedra caliza dura (Jurásico terciario) extraída del Cerro de la Cruz (Calvario) a $1 \mathrm{~km}$ de distancia de la tumba. Todas las losas están labradas en su cara interior, así como en los laterales y en los bordes superiores con herramientas de piedra. La combinación de los ortostatos individuales y de las cobijas es del mismo modo que el encaje entre la cubierta y la pared muy precisa; la comparación con los demás sepulcros de corredor y galerías andaluzas, indica el trabajo mucho más meticuloso. Debido a la forma regularmente rectangular de las losas, raramente aparecen ángulos vacíos en las esquinas superiores e inferiores; por lo tanto, casi no resultó necesario añadir ningún complemento de relleno de piedra a las paredes de losas en ninguna parte. En los pequeños huecos entre la pared y el techo se han introducido cuñas de piedra. El grosor de los ortostatos es de aproximadamente 1,0 m, el de las cobijas es de hasta 2,0 m. Mortillet ofrece una tabla con todas las dimensiones.

Para unas paredes tan finamente acabadas apenas hay parangón en toda la región atlántica. Si descartamos debidamente los sepulcros circulares, revestidos con losas finas, pertenecientes a otro grupo arquitectónico, solo quedan algunos diseños antiguos de cámaras trapezoidales en el litoral oeste portugués ${ }^{4}$, que aún requieren una revisión. En el sureste, por el contrario, se dispone de varios ejemplos, entre los que señalamos especialmente el Sepulcro 1 de Alicún (Lam. 126,4). El ensamblaje de las losas mediante el desarrollo de un pliegue solo se efectúa únicamente en la losa de tope izquierda de la entrada de la cámara.

De las cuatro cobijas de la cámara, la que cubre la parte posterior de la cámara es la más grande. No sobrepasa el ortostato de la parte posterior, que solo debe ser considerado un punto de apoyo como los pilares; la principal carga de la cubierta es soportada por los laterales. Falta el trazado preciso, de hasta qué distancia sobresalen las cobijas por los laterales de las paredes. La dimensión máxima de la cobija aceptada hasta ahora, con $8,0 \times 6,30 \mathrm{~m}$ de longitud, todavía se queda detrás de la realidad, ya que en la parte más ancha de la cámara podría significar que la cubierta apenas sobresaldría más allá de la pared. Todavía habría que investigar, si la pared sostiene o si, como ocurre en Gandul, solo lo hace el muro de relleno.

Pilares: La cubierta de la cámara es soportada por tres pilares centrales que dividen el espacio en la dirección de su eje longitudinal en dos naves. Estos pilares se encuentran exactamente debajo de las juntas de las cobijas. Se encuentran groseramente desbastados, su sección transversal es irregularmente rectangular o cuadrada. El mayor de ellos tiene una superficie en la base de 1,30 x 1,10 m. Hoy en día, perdura la impresión de un ensanchamiento hacia arriba de los pilares 1 y 2 que es engañosa, ya que la concavidad en su parte inferior con certeza debe ser atribuida a un periodo posterior. El pilar 3 se estrecha hacia arriba, aunque aquí de nuevo se debe considerar una escisión en la parte superior externa. Se puede suponer que se pretendía un espesor bastante uniforme de los pilares. Así según la información de Mergelina, están encajados en el subsuelo rocoso en fosas cónicas. Como se ha mencionado anteriormente, todavía no se han respondido todas las cuestiones en términos de profundidad de los calzos y cimentación. La colocación no completamente vertical refuerza la impresión tosca causada por las formas irregulares. Los pilares 1 y 3 se desvían hoy de la vertical entre 0,18 y $0,20 \mathrm{~m}$. Como se ha mencionado ya en casi todas las descripciones de la tumba, los pilares no están en contacto directo con la cubierta casi en ninguna parte. El pilar más alejado (3) está ligeramente redondeado por arriba y se adapta a los cantos de la cobija, de los cuales están trabajados los del anverso de la piedra. En el pilar central (2), la parte superior está curvada de forma irregular; sobre éste se encuentra la cobija del lado interior, mientras que en la del lado exterior, un espacio bastante ancho entre la cobija y el pilar está relleno con piedras pequeñas y revocos (Lam. 105, 2) [Figura 5.F]. El pilar delantero (1) se adapta mejor a la forma de la cobija, pero sin tocarla. Aquí también son visibles los rellenos.

Esta peculiaridad de la disposición de los pilares ha motivado muchas hipótesis. Obermaier, P. Paris y Hemp consideran que es posible que los pilares hubieran sido erigidos más tarde, éste último considera la posibilidad de que la rotura de la cobija 3 diera lugar a la creación de un apoyo para la cubierta. Según Hemp, la capa intermedia de piedras de relleno se concibe como una descarga de la parte superior del pilar, como una especie de ábaco. Mergelina, en cambio, cree que los pilares se colocaron antes de tener la cubierta y un error 
de cálculo produjo la diferencia involuntaria. Las investigaciones exactas de la forma y la profundidad de los calzos de los pilares deben primero dar el fundamento para la pregunta: a saber, si una erección posterior habría sido en realidad técnicamente posible. El tratamiento de los bordes de las cobijas respaldaría una teoría de tal índole. Así que, por el momento, antes de que se realice el estudio definitivo de la construcción, solo es posible abordar la pregunta desde un punto de vista cultural. En este caso nosotros opinamos que la erección de los pilares está en cualquier caso dentro del periodo de construcción de la tumba. El rico material de comparación disponible para la construcción de los pilares de este periodo nos lleva a esta suposición. Además, el uso de revoco en el sudeste pertenece por completo al apogeo de esta época cultural, con lo cual aquí ya queremos expresar nuestra suposición de que los pilares, que hoy parecen más toscos que los ortostatos, originalmente estaban enlucidos con revoco, tal vez también decorados con pintura, para lo cual existen ejemplos en Los Millares y Belmonte. Con respecto a la cobija consideramos que es posible, que precisamente una tensión falsa debida a la erección irregular de los pilares haya provocado o fomentado la rotura por el desmoronamiento de las capas intermedias.

La ejecución técnica, de la cual da testimonio la construcción, siempre ha suscitado asombro y admiración. El espacio reconstruido con un escaso número de losas tiene un volumen de 200 metros cúbicos; solamente la cámara ya cubre 67 metros cuadrados. Los cálculos sobre las losas de piedra dan para la cobija más grande, que es de 2,0 m de grosor, con un volumen de al menos 60 metros cúbicos, un peso de al menos 170 toneladas. P. Paris pregunta "¿Qué arquitecto de nuestros días se atrevería, si trabaja exclusivamente con losas de piedra, a poner tal masa sobre tal hueco?". La pregunta sobre la posible erección de la construcción con los medios de esa época, ha sido pues frecuentemente discutida por los arquitectos en particular, por esto nos referimos al detallado ensayo que Mergelina dedica a esta pregunta.

La Cueva de Menga es una de las pocas tumbas y, entre éstas, la más impresionante, en la que el concepto de construcción de un puro edificio megalítico -la pared imponente y la cubierta pesada- forma una sala interior y hace que aumente el efecto artístico. La impresión es, a pesar de los enormes bloques, de libertad y armonía; los pilares reducen el espacio en menor medida que la cargazón recogida de la vertical, llevando la extrema carga de la cubierta a una medida equilibrada. La ligera convexidad de la pared ensancha la planta de la cámara mucho más de lo que cabría esperar, lo cual causa ciertamente la impresión de una sala modelada y no de una galería larga. Las paredes cerradas sobre sí mismas se pierden en la penumbra del fondo, el cual parece más redondeado, ya que los pilares ocultan la losa frontal; el juego de luces en las paredes y el suelo causado por las posiciones de los pilares anima la sala pintorescamente.

La impresión solemne de esta sala de dos naves coincide con nuestra idea de construcciones sagradas. Esta convincente comparación con la arquitectura diseñada deliberadamente deja la pregunta de si más allá de la pura técnica, también se tuviera aquí ya el conocimiento sobre las leyes de la construcción artística a cerca de la configuración de las formas y pilares mencionados. Ciertamente, el efecto se basa principalmente en los principios originales del diseño arquitectónico, que aquí nos dirigen hacia la forma más primitiva, que nos hace remontarnos a un momento de la historia arquitectónica donde lo que la construcción exigía como conveniente, reforzado por la magnitud del objetivo, produce un efecto artístico inmediato, lo cual no se formaría en base a la cognición hasta épocas posteriores. Este es sin embargo solo un componente del efecto de la construcción. El segundo se encuentra inconfundiblemente en el ensanchamiento de la sala a través de la dirección de la pared, es decir, una modificación adquirida de la construcción circular. El modo en que se establecen los estrechos límites de esta modificación en la construcción megalítica pura, procede de toda la historia de los sepulcros de corredor poligonales. Los sepulcros más grandes de planta puramente octogonal en el interior portugués nunca han logrado crear un interior que resulte impresionante. La ampliación del espacio más allá de la dimensión alcanzada allí de aproximadamente $6 \mathrm{~m}$ de diámetro siempre se debe atribuir a formas espaciales largas. También en la Cueva de Menga, el redondeo de la pared es solo débil, porque la cubrición no permite aventurar la superación de anchuras más grandes.

La posición de la Cueva de Menga está determinada por su forma arquitectónica, según se deduce de ésta, y su importancia fue establecida ya por Gómez Moreno [Martínez]. Hasta qué punto los sepulcros de diseño parecido que han proporcionado hallazgos, detalles de la construcción y comparaciones con sepulcros del sureste pueden hacernos avanzar en la investigación de su cronología, solo puede mostrarlo el resumen.

Excavaciones (Lam. 58, Sepulcro 2) [Figura 4.B]: La excavación de Mitjana en 1842 no dio ningún resultado. 
Según Trinidad de Rojas (1874) se encontraron en la tumba "toscas herramientas de piedra dura oscura". Don Mariano de Mazas encontró en una pequeña excavación en 1904, en el ángulo formado por la piedra frontal con la pared lateral derecha, a $0,50 \mathrm{~m}$ de profundidad, un hacha de piedra de serpentina negruzca, cuello grueso, sección transversal ovalada, filo desgastado, totalmente pulida (2) [Figura 4.B.2]. Mergelina encontró una segunda hacha en la primera losa de la pared izquierda de la cámara desde el exterior, muy cerca de la pared: azuela plana de cuello ancho con una sección transversal rectangular, de roca negruzca y con la parte superior arqueada y el filo bien pulido (1) [Figura 4.B.1]. Además, Mergelina encontró una herramienta tosca con forma de disco: una especie de hacha de mano, por un lado, para colocar bien en la mano y por el otro provisto de un filo tosco, que supone se trataba de una herramienta para trabajar las piedras de la tumba. Las herramientas de piedra mencionadas por Rojas eran probablemente del mismo tipo.

\section{Ajuares según Obermaier y Mergelina.}

Grabados: en el tercer ortostato de la izquierda del corredor, se encuentra, a 0,14-0,20 m bajo la cubierta una serie de símbolos grabados (a) [Figura 4.B.a] (Lam. 140,2) [Figura 5.C]. Se trata de cuatro cruces de 0,18 - 0,47 $\mathrm{m}$ de longitud, tres de las cuales tienen una base semicircular, que en dos de ellas sobresalía ligeramente de la superficie de la roca, la tercera está determinada por dos profundos surcos en su contorno. A 0,18 m por debajo de la segunda cruz a la izquierda se encuentra una estrella de cinco puntas de $0,18 \mathrm{~m}$ de diámetro igualmente trabajada en superficie. Esta está más clara y menos patinada que las cruces, lo que se puede explicar porque cerca de la junta de la cubierta la humedad era más efectiva. La pertenencia de los grabados al periodo de construcción es probable según los grabados del dolmen de Soto. En la parte superior de la última piedra de la pared derecha de la cámara notamos rastros de otro grabado (b) [Figura 4.B.b]. Tiene $14 \mathrm{~cm}$ de longitud y probablemente pertenece a la misma época.

Grabados según los dibujos de Leisner.

\section{Cueva de Viera}

Lam. 57. 58; Imágenes: Lam. 106.

Situación: La cima de la colina tumular, en cuya vertiente nororiental se construye la Cueva de Menga, forma al suroeste, hacia la ciudad, una meseta ondulada que desciende ligeramente. A $88 \mathrm{~m}$ sur-suroeste de la entrada de Menga se abre la Cueva de Viera.

Forma: sepulcro de corredor; longitud total de $21,40 \mathrm{~m}$.

Orientación: E. $10^{\circ} \mathrm{S}$.

Exploración: El sepulcro fue descubierto en 1903 por Don José Viera Fuentes, jardinero de Antequera, de quien ha tomado su nombre. El descubrimiento y las primeras excavaciones fueron realizadas por Viera y su hermano. El sepulcro ya había sido saqueado en aquel entonces. Los primeros informes científicos fueron elaborados por Velázquez Bosco y Gómez-Moreno [Martínez].

Conservación: La cámara permanece casi intacta; en el corredor, en 1933, se habían derrumbado diversas losas de la pared y parte de la cubierta; se está trabajando en una reconstrucción del corredor y la estabilización de la colina tumular del sepulcro. La sección exterior del corredor se encuentra parcialmente destruida. Los saqueadores hicieron un agujero en la pared rocosa detrás del ortostato del fondo y en él mismo y luego ahuecaron un corredor detrás del lateral derecho de la cámara - y de la pared del corredor.

El material de construcción - piedra caliza amarillenta con incrustaciones de cuarzo - es el mismo que para la Cueva de Menga y provienen igualmente de la cantera del Cerro de la Cruz.

La elaboración y el ensamblaje de las losas demuestran, especialmente en la cámara, un cuidado y calidad de trabajo único de las construcciones megalíticas de la Península Ibérica. Por esto, Velázquez Bosco asume el trabajo con herramientas de metal y también GómezMoreno [Martínez] se inclinó por este punto de vista, sin embargo, posteriormente, mediante un examen minucioso se determinó que las superficies de impacto redondas y conoidales en las losas tuvieron que hacerse con un cincel o con hachas de piedra. Relativo al proceso de construcción: en una zona expuesta por los saqueadores se puede ver en el borde de la excavación marcas de palancas que habrían servido como recurso para la colocación de los ortostatos.

Forma y construcción: el espacio para el sepulcro está, como en la Cueva de Menga, socavado en el subsuelo rocoso - toba calcárea - de la colina tumular. El borde de la zanja en la roca se encuentra aproximadamente $0,70 \mathrm{~m}$ más profunda que el borde superior de la cobija de la cámara; su pared se encuentra $0,60 \mathrm{~m}$ por detrás de los ortostatos. El espacio intermedio está relleno con un muro de capas - alternas de piedras y arcilla -. Detrás de los ortostatos desplomados del corredor 
vimos trozos de losas individuales empotradas en arcilla.

Cámara: cuadrada, de 1,75 m de largo y ancho. La sala crea un cubo algo sobredimensionado en altura con 2,08 $\mathrm{m}$ de altura, está construida con cuatro ortostatos, la losa frontal y la losa de la puerta provista de un agujero cincelado, son las piedras principales de la cámara y son más altas que las losas de las paredes laterales, superándolas incluso en ancho y grueso. En su cara interna se han preparado unos pliegues verticales, en los que las piedras laterales están ajustadas en una unión perfecta.

Los ortostatos de la cámara se encuentran en vertical; la fortaleza del engranaje de la pared garantiza, para las medidas limitadas de la sala, una estabilidad suficiente, incluso sin inclinación interna. La cámara está cubierta con una gran losa de $0,65 \mathrm{~m}$ de grosor, cuyas dimensiones se indican en la literatura anterior con 5,0 x 5,0 m. En la planta de Mergelina la cobija es, en su extensión hacia atrás, algo más corta $(3,60 \mathrm{~m})$.

El suelo de la cámara está formado hoy en día por la roca natural algo erosionada; según el trazado de Velázquez Bosco está algo más abajo que el del corredor; y en él se encuentra un agujero redondo hecho por los saqueadores, quienes al mismo tiempo quizás también hayan arrancado el pavimento.

Corredor: El acceso a la cámara sepulcral consta de dos secciones claramente diferenciadas en planta y según el modo de construcción.

Antecámara principal: Esta parte más cercana a la cámara tiene 1,30 - 1,35 $\mathrm{m}$ de ancho y 15,60 $\mathrm{m}$ de longitud. A esta distancia de la entrada a la cámara se hayan los restos de una segunda puerta perforada. La parte del sepulcro, que por esto está caracterizada como espacio de enterramiento, se limitaba originalmente por 12 - 13 losas en cada pared, de las que hoy faltan 4. Las paredes discurren paralelas la una a la otra; los ortostatos, de anchura variable, están bien juntos e inclinados ligeramente hacia dentro. La altura de la antecámara principal asciende hoy día a 2,10 m en la cámara y 1,90 $m$ en la losa de la puerta exterior debido al descenso de la cubierta. Velázquez Bosco fija la altura del corredor en 2,40 m, lo que según la ubicación de los agujeros de las puertas es poco probable. Las cobijas no se apoyan directamente en los ortostatos, pues entre ambos se interpone una capa fina de lajas de pizarra, parcialmente trabadas con barro. Esta particularidad de la construcción se encuentra también en la cámara. La Lám. 106,1 [Figura 7.A] muestra claramente esta capa intermedia; así mismo de la imagen se deduce que la cobija de la cámara se encuentra algo más baja que las cobijas del corredor y está algo más avanzada de lo que se desprende del alzado de Mergelina. El contorno de Velázquez Bosco exagera un poco esta parte de la construcción, pero es más correcto. No hay ninguna información disponible sobre la altura real de los ortostatos y su fijación en el suelo. El suelo transcurre en horizontal; los puntos de las bases de los agujeros de las puertas se encuentran a la misma altura. Originalmente estaba pavimentado con finas lajas. Entre el pavimento y la roca se encontraba una capa de tierra. Según Santos Rocha, quien utiliza un informe de F. Francesco y Lozano, había lajas pequeñas colocadas en parte en vertical y estaban conectadas por finas lajas de piedra negruzca. El informe acerca de esto no es del todo claro.

De la cubierta se han conservado las cuatro cobijas que se encuentran muy cerca de la cámara, más irregulares en la forma que las de la Cueva de Menga, no obstante, están bien unidas, con un grosor máximo de 0,80 $\mathrm{m}$. Restos de dos cobijas rotas más se encuentran en el lado derecho de la pared. La más exterior de ellas, de $0,45 \mathrm{~m}$ de espesor, se encuentra directamente sobre la losa de la puerta del corredor. Las cobijas sobresalen de las paredes laterales hasta $1,70 \mathrm{~m}$, por lo que en todos los casos se apoyan en la roca natural. Entre el borde superior de la zanja en la roca y las cobijas se encuentra un muro de capas de arcilla y lajas (c) [Figura 8].

Losa portal 1. Puerta de la cámara (b) [Figura 8] (Lam. 106,1) [Figura 7.A]: En el ortostato delantero de la cámara, de $0,60 \mathrm{~m}$ de espesor, se ha cincelado un hueco de puerta rectangular. Altura: por la izquierda $0,87 \mathrm{~m}$, por la derecha $0,85 \mathrm{~m}$. Anchura: abajo 0,72 m, arriba $0,75 \mathrm{~m}$. Las superficies interiores laterales se han trabajado lisas, no curvas. El umbral es una superficie recta y ligeramente inclinada hacia la cámara. El borde interior superior está redondeado hacia abajo; algo irregular, de tal manera que se crea una ligera cresta, que está algo más cercana al lateral de la cámara. Se supone según eso, que el cincelado se llevó a cabo desde ambos lados. El borde superior del hueco de la puerta se encuentra a $0,88 \mathrm{~m}$ por debajo de la cobija, el inferior a 0,25 m sobre el suelo de hoy día, probablemente 0,30 - 0,35 m sobre el suelo original. La distancia del hueco de la puerta hacia los ortostatos de la pared es de 0,25 $\mathrm{m}$ por la izquierda y a $0,35 \mathrm{~m}$ por la derecha; el ancho total visible de la losa de puerta desde el exterior, por consiguiente, es de 1,35 m (Lám. 106,1) [Figura 7.A].

Losa portal 2. Puerta del corredor (a) [Figura 8] (Lám. 106, 2) [Figura 7.B]: En esta losa de puerta se ha cincelado un hueco rectangular de $0,98 \mathrm{~m}$ de altura y $0,76 \mathrm{~m}$ de ancho; sobre el orificio, la losa se encuentra rota en la actualidad casi en la totalidad del ancho 
del hueco, solo en los bordes superiores derecho e izquierdo de la piedra reconocimos en nuestra visita del 16 de febrero de 1933 un saliente de muy pequeño tamaño en la pared lisa, sobre el que se desarrollaba la superficie de rotura. Esto nos indujo a investigar el suelo, lo que nos condujo al descubrimiento del borde inferior completamente conservado de un hueco portal cincelado. En la literatura anterior esto no se menciona en ninguna parte; Hemp publica el hueco de la puerta, cuyo borde inferior dejamos al descubierto nosotros, en un artículo de octubre de 1934. Visto desde el exterior, los lados interiores del orificio de la puerta se desvían de la vertical en la parte superior $5 \mathrm{~cm}$ hacia la izquierda; están, así como el umbral, labrados lisos, las esquinas están ligeramente redondeadas. La losa portal tiene $0,50-0,60 \mathrm{~m}$ de grosor y un ancho visible de $1,20 \mathrm{~m}$. Al tiempo que pudimos verificar que la losa portal, hacia la izquierda desde el borde del hueco, ha contado al menos con una anchura de $0,65 \mathrm{~m}$, se puede suponer una anchura total de 2,0 m. La altura desde del borde superior del orificio hasta la cubierta es de 0,53 $\mathrm{m}$, con lo cual es menor que en la piedra portal de la cámara, lo que corresponde a la caída de la cubierta ya mencionada. La altura del umbral es de suponer conforme a la puerta de la cámara de $0,30-0,35 \mathrm{~m}$, la altura de la piedra portal, con 1,80 - 1,85 m coincide con la altura del corredor medida hasta ahora en este punto. Como es habitual en Los Millares, aquí también el hueco exterior del portal es mayor que el interior.

Tramo de corredor exterior: en el exterior del portal del corredor se encuentran hoy tres ortostatos, dos a la derecha y uno a la izquierda. Esta última, de la misma altura que los ortostatos por dentro del portal del corredor, demuestra, que el exterior del corredor en este punto es igual de alto que la antecámara principal. Los ortostatos del lado derecho son algo más bajos. Todas las losas están peor trabajadas que las del interior de la tumba. Los ortostatos todavía existentes tienen una longitud de 2,70 m; al exterior, todavía es visible la tumba desde dos metros más, luego sigue el terreno natural ligeramente inclinado. El ancho en la losa portal es de 1,20 m, por tanto, corresponde con el de la parte externa de la antecámara principal.

Túmulo: El túmulo, construido con arcilla y piedras, tiene un diámetro de $35 \mathrm{~m}$ y está conservado hoy en día en casi 4 metros de altura sobre la cámara.

La Cueva de Viera se sitúa arquitectónicamente en el polo completamente opuesto a la Cueva del Romeral; como allí el pensamiento de la bóveda y de la curva, está aquí la base de la construcción en el ángulo recto. Entre las tumbas megalíticas de la Península, ninguna de ellas, en cada detalle - planta, disposición vertical, formas de las losas, huecos de los portales - representa consistentemente ese principio de construcción.

Enterramiento, ajuar: el saqueo completo del sepulcro no permitió ninguna observación sobre la ubicación de los enterramientos. Los hallazgos son también escasos debido a los saqueos. Los sitios exactos no se conocen. La cámara estaba llena de tierra negra, en donde se hallaron algunos pequeños huesos.

De la antecámara principal proceden los siguientes objetos (Lam. 58, Sepulcro 3) [Figura 4.C]:

Piedra pulida: Pequeña hacha afilada con sección transversal ovalada, dañada en el filo. Piedra granulada, gris (1) [Figura 4.C.1]. Hacha plana de cuello ancho con corte transversal de forma trapezoidal, lado superior arqueado, piedra negruzca (2) [Figura 4.C.2].

Sílex: 14 fragmentos de láminas finas, longitud 4,6 - 8,1 cm (6 - 12) [Figura 4.C.6-12]. Destacan las siguientes piezas: $n^{\circ}$ 8.10: finos fragmentos de láminas de sección transversal trapezoidal y retoque del borde circular. $\mathrm{N}^{\circ}$ 11: parte superior de una lámina más ancha con retoque del borde en ambos lados. $\mathrm{N}^{\circ} 12$ : lámina estrecha, muy fina y delgada con finos retoques de sierra en los dos bordes. $\mathrm{N}^{\circ}$ 9: fragmento de lámina con forma de buril puntiagudo. Otros 7 fragmentos más pequeños de láminas similares, entre ellos dos puntiagudos como la $\mathrm{n}^{\circ} 9$.

Huesos: 1 fragmento de hueso (3) [Figura 4.C.3]. 1 Punta de cuerno (4) [Figura 4.C.4].

Piedra caliza: recipiente de piedra. Piedra blanca en forma de disco, ahondada en ambos lados (14) [Figura 4.C.14]. Junto a esta piedra se encontró el punzón de cobre. 1 recipiente de pie, pared abultada, bruscamente retraída debajo del borde, suavemente ahondado (13) [Figura 4.C.13]. 2 bolas de piedra caliza del tamaño de una naranja.

Cobre: 1 punzón de cobre de $8 \mathrm{~cm}$ de largo, una sección transversal triangular, con ambos extremos apuntados (5) [Figura 4.C.5].

Moluscos: 9 moluscos, entre ellos 2 Patella (18) [Figura 4.C.18]. Los moluscos restantes no están, según la imagen, exactamente identificados, ¿6 Pectúnculos (o Cardium), 1 Pecten? (16. 17) [Figura 4.C.16-17].

Cerámica: 1 cuenco hemisférico, $10,5 \mathrm{~cm}$ de diámetro en el borde, con $4,5 \mathrm{~cm}$ de altura, encontrado junto a la puerta del corredor. Fragmentos de vasijas de tonos negros. Fragmentos de una vasija grande y gruesa, pasta fuertemente micácea. Fragmentos de $1 \mathrm{~cm}$ de grosor con mamelones (15) [Figura 4.C.15].

En el corredor: Pedazo de una mandíbula de bovino con dentición. 
Fragmentos de tejas romanas.

Todos los objetos propiedad de Don J. Viera, Antequera; excepto el $n^{\circ}$ 13: propiedad del Sr. Anson, Antequera. $\mathrm{N}^{\mathrm{o}} 15$ propiedad de W. J. Hemp, Inglaterra.

Ajuar según Mergelina, $\mathrm{N}^{\circ} 15$ según Hemp.

Cazoletas: una losa de la antecámara está cubierta con una gran cantidad de cazoletas. En varias losas de las proximidades de la puerta del corredor se encuentran también cazoletas, de 3 - $5 \mathrm{~cm}$ de diámetro y de hasta 3 $\mathrm{cm}$ de profundidad.

Hallazgos en el territorio de Antequera. Cerca de los sepulcros, en el Cerro de Marimacho, según Gómez-Moreno [Martínez], durante muchos años, se han encontrado objetos de cerámica hechos a mano, láminas de sílex y hachas de piedra - del mismo tipo que las encontradas en la Cueva de Viera - de serpentina, que es común en la provincia.

1) Informe de hallazgos de Gómez-Moreno [Martínez]; enumeración exacta de los hallazgos óseos adicionales cerca de estos, Arquitectura tartesia 93 Anm. 1; también Mergelina, Necrópoli tartesia 83.

2) Góngora, Antigüedades de Andalucía 89. 90.

3) Si el boceto de construcción de Mergelina a. a. O. 58 no está del todo claro que las investigaciones sobre esta tumba se tomen en términos generales.

$\left.{ }^{4}\right)$ Anta da Arruda, Anta da Capella. 